Article

\title{
In Depth Analysis of Photovoltaic Performance of Chlorophyll Derivative-Based "All Solid-State" Dye-Sensitized Solar Cells
}

\author{
Michèle Chevrier ${ }^{1,2}$, Alberto Fattori ${ }^{3}$ (D) , Laurent Lasser ${ }^{4}$, Clément Kotras ${ }^{1,4}$, Clémence Rose ${ }^{1}$, \\ Michela Cangiotti ${ }^{3}$ (D), David Beljonne ${ }^{4}\left(\mathbb{D}\right.$, Ahmad Mehdi $^{1}\left(\mathbb{D}\right.$, Mathieu Surin $^{4}$, Roberto Lazzaroni ${ }^{4}$, \\ Philippe Dubois ${ }^{2}$ (D), Maria Francesca Ottaviani ${ }^{3}$, Sébastien Richeter ${ }^{1, *}$, Johann Bouclé ${ }^{5, *(\mathbb{D})}$ and \\ Sébastien Clément ${ }^{1, *(D)}$ \\ 1 ICGM, Univ. Montpellier, CNRS, ENSCM, CC1701, Place Eugène Bataillon, 34095 Montpellier, France; \\ Michele.chevrier@stepaneurope.com (M.C.); clement.kotras@umontpellier.fr (C.K.); \\ clemence.rose@umontpellier.fr (C.R.); ahmad.mehdi@umontpellier.fr (A.M.) \\ 2 Service des Matériaux Polymères et Composites (SMPC), Centre d'Innovation et de Recherche en Matériaux \\ et Polymères (CIRMAP), Université de Mons, 20 Place du Parc, 7000 Mons, Belgium; \\ philippe.dubois@umons.ac.be \\ 3 Department of Pure and Applied Sciences (DiSPeA), University of Urbino, 61029 Urbino, Italy; \\ alberto.fattori@uniurb.it (A.F.); michela.cangiotti@uniurb.it (M.C.); maria.ottaviani@uniurb.it (M.F.O.) \\ 4 Laboratory for Chemistry of Novel Materials, CIRMAP, University of Mons UMONS, 20 Place du Parc, \\ 7000 Mons, Belgium; laurent.lasser@umons.ac.be (L.L.); david.beljonne@umons.ac.be (D.B.); \\ mathieu.surin@umons.ac.be (M.S.); roberto.lazzaroni@umons.ac.be (R.L.) \\ 5 CNRS, Univ. Limoges, XLIM, UMR 7252, F-87000 Limoges, France \\ * Correspondence: sebastien.richeter@umontpellier.fr (S.R.); johann.boucle@unilim.fr (J.B.); \\ sebastien.clement1@umontpellier.fr (S.C.); Tel.: +33-(0)4-67-14-39-71 (S.R. \& S.C.); +33-(0)5-87-50-67-62 (J.B.)
}

Academic Editors: Ahmad Mehdi and Sébastien Clément

Received: 27 November 2019; Accepted: 28 December 2019; Published: 3 January 2020

\begin{abstract}
Chlorophyll a derivatives were integrated in "all solid-state" dye sensitized solar cells (DSSCs) with a mesoporous $\mathrm{TiO}_{2}$ electrode and $2^{\prime}, 2^{\prime}, 7,7^{\prime}$-tetrakis[N,N-di(4-methoxyphenyl)amino]-9,9'-spirobifluorene as the hole-transport material. Despite modest power conversion efficiencies (PCEs) between $0.26 \%$ and $0.55 \%$ achieved for these chlorin dyes, a systematic investigation was carried out in order to elucidate their main limitations. To provide a comprehensive understanding of the parameters (structure, nature of the anchoring group, adsorption ... ) and their relationship with the PCEs, density functional theory (DFT) calculations, optical and photovoltaic studies and electron paramagnetic resonance analysis exploiting the 4-carboxy-TEMPO spin probe were combined. The recombination kinetics, the frontier molecular orbitals of these DSSCs and the adsorption efficiency onto the $\mathrm{TiO}_{2}$ surface were found to be the key parameters that govern their photovoltaic response.
\end{abstract}

Keywords: solid state dye sensitized solar cells; spirulina; chlorophyll; anchoring groups; EPR

\section{Introduction}

Fossil fuel resource exhaustion, increasing energy demands and environmental problems have triggered an intensification of research for sustainable energy sources, which lead to the development of photovoltaic devices, fuel cells, wind turbines, etc. Photovoltaic conversion of solar energy is considered to be one of the most significant ways of addressing the growing global energy crisis [1]. In this context, utilizing biomass resources for the conversion of solar energy has been receiving increasing attention from industry, academia and governments and will become a major challenge of 
our future [2-4]. Biomass has a great potential as a renewable feedstock for producing solar energy [5,6]. Indeed, protein-pigment complexes in plants, green algae, and cyanobacteria convert solar energy into chemical energy through oxygenic photosynthesis with high efficiency [7-9]. Calvin showed through a model based on a photosynthetic electron transport system containing membranes, carotenoids and pigments that electric energy can be obtained by conversion of sunlight [10]. A similar approach based on an artificial photosynthesis led in 1991 to dye-sensitized solar cells (DSSCs, also known as Grätzel cells) [11]. A DSSC consists of a mesoporous nanocrystalline $n$-type semiconductor (typically $\mathrm{TiO}_{2}$ ) sensitized with a dye, deposited onto an anode and immersed in redox active electrolyte (generally triiodide/iodide), completed by a counter-electrode (cathode) [12]. Upon illumination, dye molecules anchored onto the $\mathrm{TiO}_{2}$ surface absorb incoming photons, allowing the photoinduced electron-transfer from their excited state into the $\mathrm{TiO}_{2}$ conduction band. Then, the electrons are transferred to the counter electrode, thus creating a current. The redox electrolyte reduces the oxidized dye molecules back to their ground state to enable continuous electron production. Even if power conversion efficiencies (PCEs) above 13\% have been reached for liquid-electrolyte DSSCs $[13,14]$, improvements are still required in order to be commercially viable.

First, there is a crucial need for solid-state approaches since the use of liquid electrolytes is a major hurdle for commercialization by industry due to the corrosive nature of the commonly used $\mathrm{I}_{3}{ }^{-} / \mathrm{I}^{-}$redox shuttle $[15,16]$. DSSCs incorporating solid-state hole transport materials (HTMs) have been actively investigated [17-19], and decent efficiencies close to $12 \%$ have been already achieved by molecular and inorganic HTMs combined with state-of-the-art organic dyes [20,21]. Additionally, solid-state DSSCs (ssDSSCs) led to a major breakthrough by using hybrid lead halide perovskite sensitizers such as $\mathrm{CH}_{3} \mathrm{NH}_{3} \mathrm{PbI}_{\mathrm{x}} \mathrm{Cl}_{3-\mathrm{x}}$, enabling the advent of perovskite solar cells with efficiencies now above $25 \%$ [22]. However, important issues concerning the device stability and the toxicity of the components still remain.

Secondly, it is highly required to use efficient and cost-effective dyes in place of expensive and scarce ruthenium complexes [23,24] or elaborated organic dyes requiring numerous synthetic steps $[15,25]$. In contrast, natural organic dyes and their derivatives are promising candidates for developing DSSCs due to their low cost, abundance and non-toxicity [5]. An important biomass resource developed in the south of France is spirulina, a green algae mainly used as food supplement. One of the most valuable compound that can be extracted from spirulina is chlorophyll $a,(\mathrm{Chl} a-12 \mathrm{~g} / \mathrm{kg}$ ) [26] a photo- and electroactive chlorin-type macrocycle involved in photosynthesis, because it efficiently absorbs light in the $400-450 \mathrm{~nm}$ and the $600-700 \mathrm{~nm}$ regions and up to $800 \mathrm{~nm}$ depending of its aggregation state [27]. The use of chlorophyll derivatives as sensitizers has been investigated in liquid electrolyte-based DSSCs leading to energy-to-electricity conversion efficiency $(\eta)$ up to around 8\% [28-30]. Concerning solid-state DSSC, there are only a few reports in the literature describing the use of chlorophyll $a$ derivatives as dye [31-33].

Herein, we report the preparation of all-solid state DSSCs using a series of Chl $a$ derivatives (Figure 1) as sensitizers with different anchoring groups to graft to the $\mathrm{TiO}_{2}$ surface and $2^{\prime}, 2^{\prime}, 7,7^{\prime}$-tetrakis[N,N-di(4-methoxyphenyl)amino]-9,9'-spirobifluorene (spiro-OMeTAD) as HTM. The choice of spiro-OMeTAD HTM was motivated by its facile implementation and high performance rendering it particularly suitable for testing DSSCs. To elucidate the relationship between the molecular structure of the dye and the photovoltaic efficiency, UV-Vis absorption spectroscopy, density functional theory (DFT) calculations, incident photon-to-current efficiency (IPCE), transient photovoltage decay measurements and EPR analysis exploiting the spin probe 4-carboxy-2,2,6,6-tetramethylpiperidine 1-oxyl (4-carboxy-TEMPO, indicated as 4C-T) have been carried out.

\section{Results}

\subsection{Synthesis of the Dyes Derived from Chlorophyll a}

The chemical structures of chlorophyll $a$-based dye sensitizers depicted in Scheme 1 were obtained from methyl pyropheophorbide- $a$ (MPPa). MPPa was prepared in four steps: (i) extraction of Chl $a$ from 
spirulina biomass with ethanol, (ii) demetallation of $\mathrm{Chl} a$, (iii) acid-catalyzed transesterification of the phytyl chain in methanol, and (iv) decarboxylation of the ester moiety located on the 13-position with 2,4,6-collidine [34,35]. Three families of corresponding free-base and zinc chlorins can be distinguished depending on the localization of the anchoring group. All the chlorins have one carboxylic acid for grafting onto the $\mathrm{TiO}_{2}$ surface. Chlorins $\mathbf{M 1 - M 2}$ exhibit a non-conjugated alkyl anchoring group while the others possess either a conjugated vinyl anchoring group (M3-M4) or a cyanoacrylic group along the $\mathrm{Q}_{\mathrm{y}}$ axis of the chlorin skeleton (M5-M6).
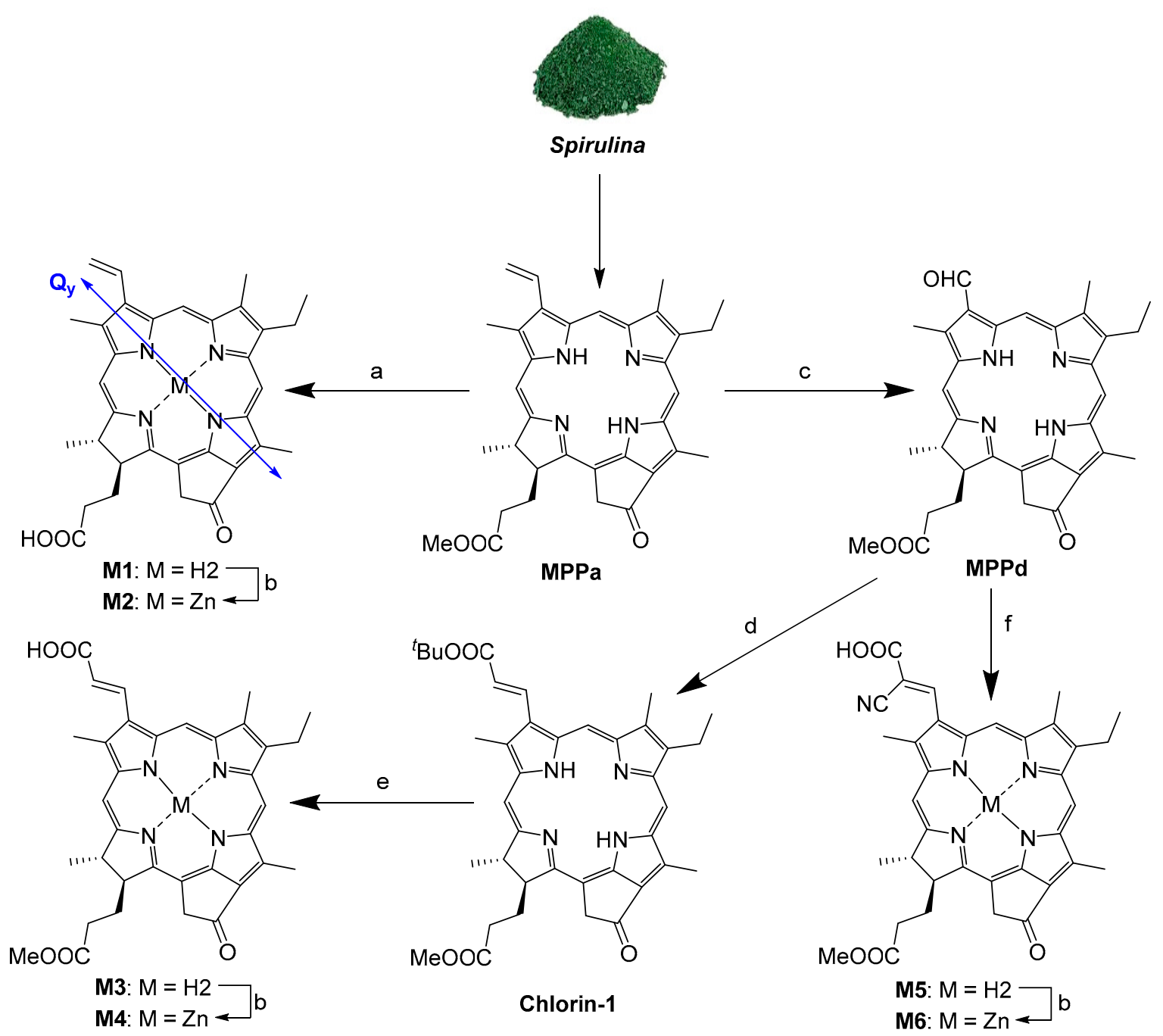

Scheme 1. Synthesis of chlorins M1-M6 from MPPa: (a) $\mathrm{HCl}$, acetone; (b) $\mathrm{Zn}(\mathrm{OAc})_{2} \cdot 2 \mathrm{H}_{2} \mathrm{O}$, $\mathrm{MeOH} / \mathrm{THF}$; (c) $\mathrm{OsO}_{4}, \mathrm{NaIO}_{4}$, dioxane-AcOH-water; (d) $\mathrm{Ph}_{3} \mathrm{P}=\mathrm{CHCOO}{ }^{t} \mathrm{Bu}_{1} \mathrm{CH}_{2} \mathrm{Cl}_{2}$; (e) $\mathrm{CF}_{3} \mathrm{COOH}$; and (f) $\mathrm{NCCH}_{2} \mathrm{COOH}$, piperidine-THF.

M1 was synthesized through the acid hydrolysis of MPPa with hydrochloric acid in acetone. Methyl pyropheophorbide- $d$ (MPPd) was prepared by cleavage of the alkene in the presence of osmium tetroxide $\left(\mathrm{OsO}_{4}\right)$ and sodium periodate $\left(\mathrm{NaIO}_{4}\right)$ [35]. Trans-32-carboxy-pyropheophorbide- $a(\mathbf{M} 3)$ was synthesized in two steps: (a) a Wittig reaction with MPPd and (b) the hydrolysis with TFA of the corresponding Chlorin-1. A Knoevenagel reaction of MPPd with cyanoacetic acid in piperidine/THF yielded chlorin M5. Finally, metalation reactions of the free base chlorins M1, M3, and M5 with $\mathrm{Zn}(\mathrm{OAc})_{2}$ in $\mathrm{MeOH} / \mathrm{THF}$ afforded the corresponding zinc complexes M2, M4, and M6. 


\subsection{Optical Properties of Chlorin Derivatives}

The UV-Visible absorption spectra of chlorins M1-M6 both in THF and grafted on the $\mathrm{TiO}_{2}$ surface through carboxylate bonding are presented in Figure 1. Table 1 summarizes their characteristics in THF and on $\mathrm{TiO}_{2}$. The shape of the UV-Visible absorption spectra in THF are relatively similar, with five observed bands when going from blue to red: Soret, $Q_{x}(0,1), Q_{x}(0,0), Q_{y}(0,1)$, and $Q_{y}(0,0)$. The $Q_{y}$ peaks position of the vinyl-substituted chlorins M3-M6 are redshifted by about 10-20 nm in comparison with chlorins M1-M2 due to the introduction of electron-withdrawing groups on the vinyl moiety at the C3 position. The bathochromic shifts of the $\mathrm{Q}_{\mathrm{y}}$ peaks of chlorins $\mathbf{M} 5-\mathbf{M} 6$ are larger than those observed for M3 (7-15 nm) and M4 (1-4 nm) because of the higher electron-withdrawing ability of the cyano group. Upon zinc metalation, the Soret absorption bands are redshifted (chlorins M2, M4, and M6), implying an increase of the conjugated $\pi$-electron delocalization along $X$ axis while the hypsochromic shift of the $\mathrm{Q}_{\mathrm{y}}$ indicates a decrease of the extent of conjugated $\pi$-electron delocalization along $\mathrm{Y}$ axis [36].

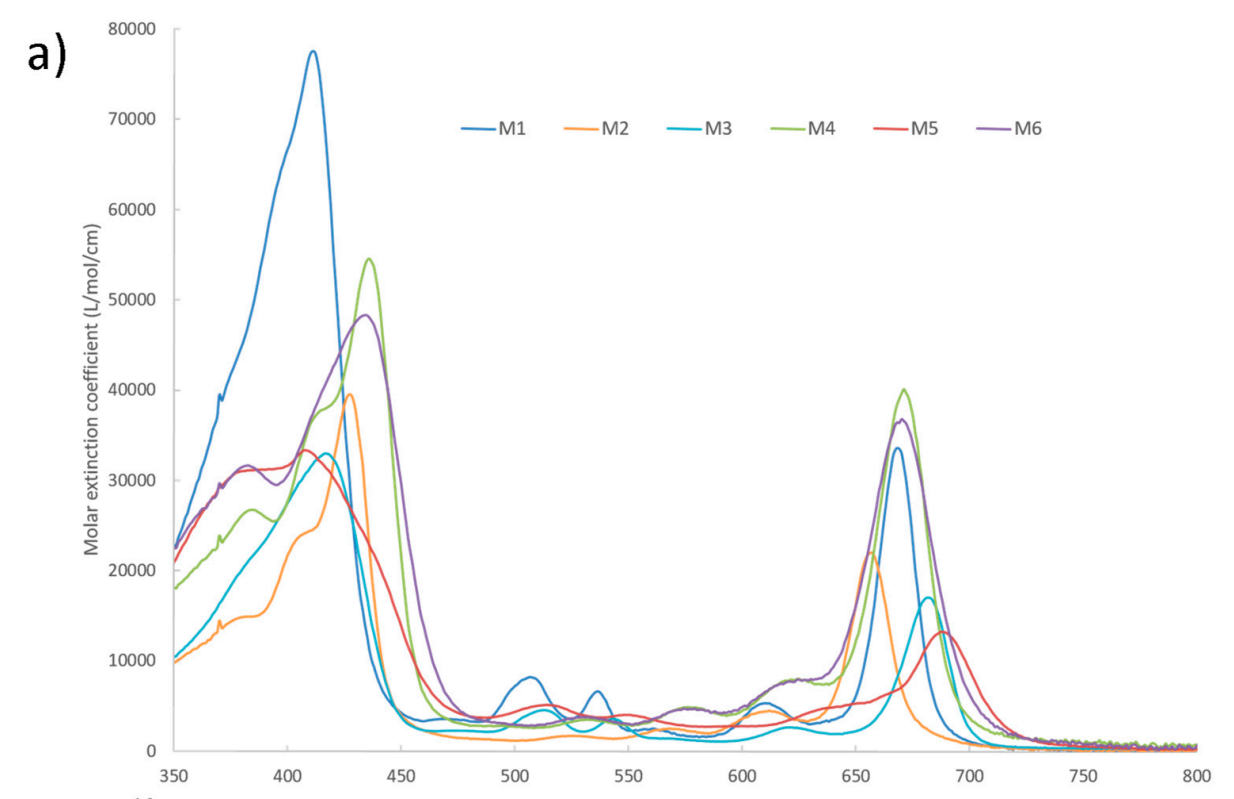

b)

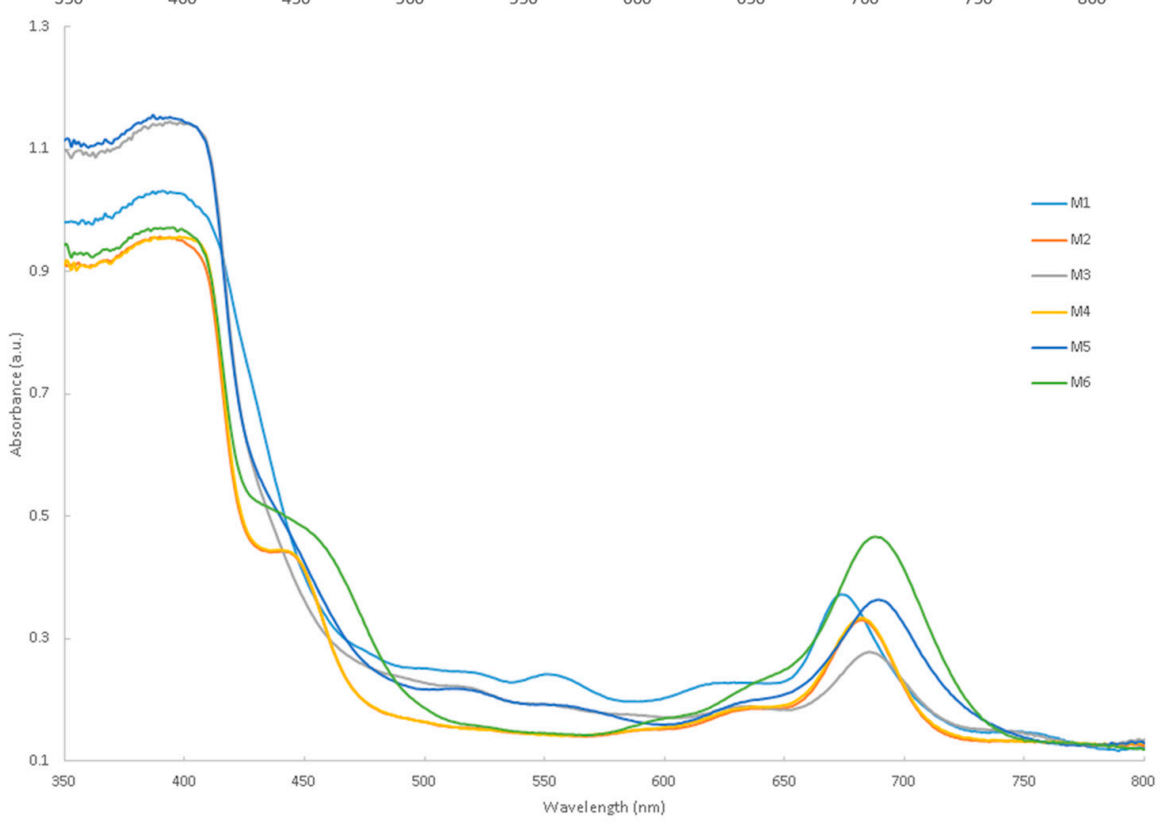

Figure 1. (a) UV-Visible absorption spectra of chlorins M1-M6 in THF and (b) grafted onto the $\mathrm{TiO}_{2}$ surface. 
The binding of the chlorin dyes onto the $\mathrm{TiO}_{2}$ surface leads to a broadening of the absorption bands, probably due to $\pi$ stacking interactions between chlorin dye molecules, as extensively studied in previous investigations [37]. The comparison of the chlorin absorption spectra in THF solutions as the monomeric species (Figure 1a) and on $\mathrm{TiO}_{2}$ as aggregates also reveal that the $Q_{Y}$ bands shift to longer wavelengths suggesting the formation of $J$ aggregates [31].

Table 1. Spectral characteristics of chlorin derivatives M1-M6 in THF solution and grafted on the $\mathrm{TiO}_{2}$ surface.

\begin{tabular}{|c|c|c|c|c|}
\hline \multirow{2}{*}{ Compound } & \multirow{2}{*}{ Solvent } & \multicolumn{3}{|c|}{$\lambda_{\max } / \mathrm{nm}$} \\
\hline & & Soret & $Q_{x}(0,1) /(0,0)$ & $\mathrm{Q}_{Y}(0,1) /(0,0)$ \\
\hline \multirow[t]{2}{*}{ M1 } & THF & 414 & $507 / 536$ & $610 / 668$ \\
\hline & $\mathrm{TiO}_{2}$ & & $520 / 553$ & $620 / 673$ \\
\hline \multirow[t]{2}{*}{ M2 } & THF & 427 & $524 / 570$ & $609 / 657$ \\
\hline & $\mathrm{TiO}_{2}$ & & $524 / 541$ & $633 / 681$ \\
\hline \multirow[t]{2}{*}{ M3 } & THF & 417 & $513 / 545$ & $621 / 681$ \\
\hline & $\mathrm{TiO}_{2}$ & & $518 / 560$ & $632 / 685$ \\
\hline \multirow[t]{2}{*}{ M4 } & THF & 436 & $531 / 576$ & $621 / 671$ \\
\hline & $\mathrm{TiO}_{2}$ & & $524 / 541$ & $631 / 681$ \\
\hline \multirow[t]{2}{*}{ M5 } & THF & 409 & $515 / 550$ & $636 / 688$ \\
\hline & $\mathrm{TiO}_{2}$ & & $518 / 560$ & $632 / 691$ \\
\hline \multirow[t]{2}{*}{ M6 } & THF & 434 & $532 / 579$ & $625 / 672$ \\
\hline & $\mathrm{TiO}_{2}$ & & $527 / 595$ & $635 / 689$ \\
\hline
\end{tabular}

\subsection{Photovoltaic Performance of Chlorin Derivatives}

\subsubsection{Influence of the Co-Adsorbent}

The $\pi$ stacking of dyes when grafted onto the $\mathrm{TiO}_{2}$ surface was evidenced from the UV-Visible absorption spectra, as discussed above. Such aggregation is known to affect the photoelectron injection efficiency and thus, the overall conversion efficiency [38,39]. A typical way to lower the dye aggregation at the semiconductor interface consists in using co-adsorbents such as chenodeoxycholic acid (CDCA), the most commonly used additive in DSSC preparation [40-42]. Indeed, its strong binding to the $\mathrm{TiO}_{2}$ surface partly displaces dye molecules, reducing their self-aggregation. Nevertheless, the addition of co-adsorbent molecules also reduces the dye loading and thus, photon harvesting. It is therefore crucial to judiciously adjust the amount of co-adsorbent used during the impregnation. To optimize the loading of the co-adsorbent in the dye solution, the impregnation was performed for $15 \mathrm{~h}$ using different concentrations of CDCA (from 0 to $3 \mathrm{mM}$ ) in a $0.3 \mathrm{mM}$ THF solution of the dye. The choice of THF was motivated by the good solubility of the free-base and zinc-metalated chlorin in that solvent.

To determine the amount of dye $\mathbf{M} 2$ grafted onto the $\mathrm{TiO}_{2}$ surface as a function of the concentration of co-adsorbent, UV-Visible absorption measurements were performed (Figure 2). Dye M2 grafted from a $0.3 \mathrm{mM}$ solution shows an absorbance of 0.55 for the Soret absorption band at around $420 \mathrm{~nm}$ and 0.25 for the lower energy $Q$ band at around $665 \mathrm{~nm}$. This value dramatically decreased when the concentration of co-adsorbent was increased up to $3 \mathrm{mM}$ and this spectral evolution is in good agreement with previous studies reported in the literature $[43,44]$. Indeed, the co-adsorbent tends to decrease the adsorption of dye $\mathbf{M} 2$ via a competitive anchoring process, thereby decreasing the dye concentration and thus, the dye aggregation onto the $\mathrm{TiO}_{2}$ surface.

The current density-voltage $(\mathrm{J}-\mathrm{V})$ characteristics of the corresponding devices were then measured and are depicted in Figure 3. The extracted photovoltaic parameters are presented in Table 2. To evaluate the efficiency of our fabrication process and thus, the accuracy of the collected data, a solar cell based on the well-known organic dye, D102, was used as reference $[45,46]$. 


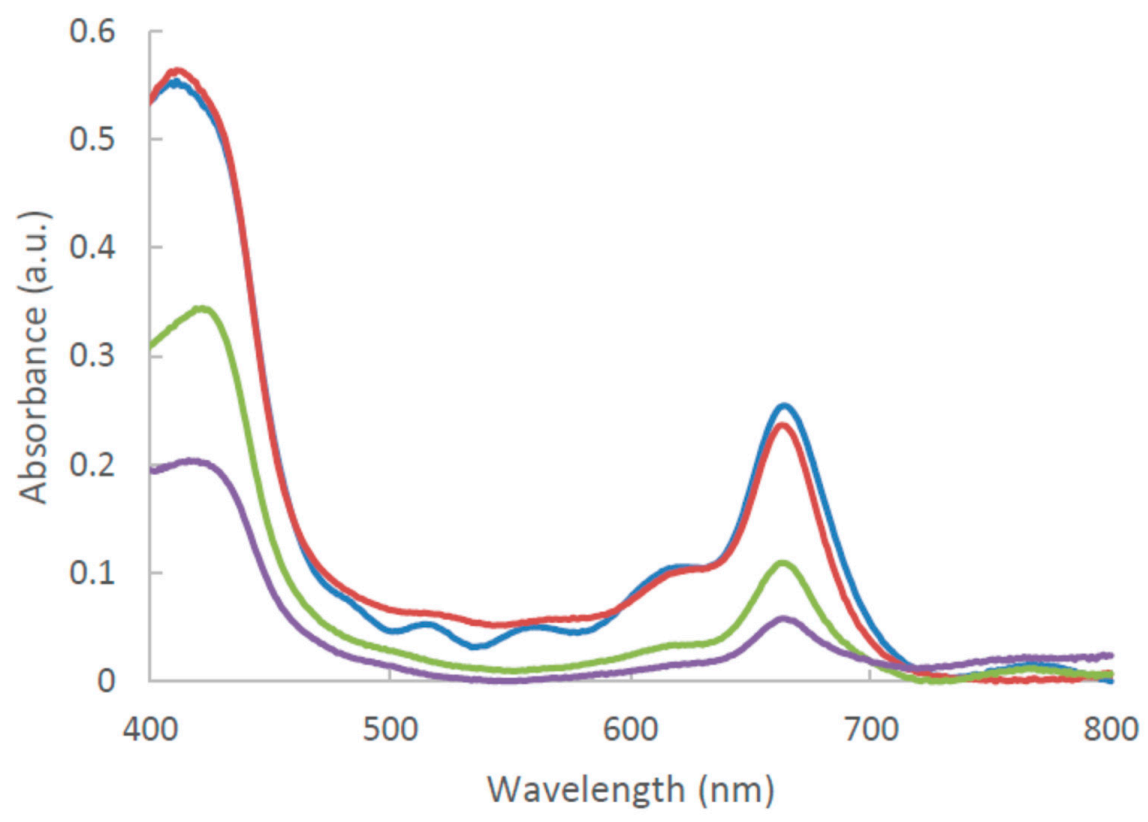

Figure 2. UV-Visible absorption spectra of $\mathrm{TiO}_{2}$ films impregnated with $\mathbf{M} 2(0.3 \mathrm{mM}$ in THF) and increasing co-adsorbent concentration $(0 \mathrm{mM}$ : blue line; $0.3 \mathrm{mM}$ : red line; $1.5 \mathrm{mM}$ : green line, and 3 mM: purple line in THF).

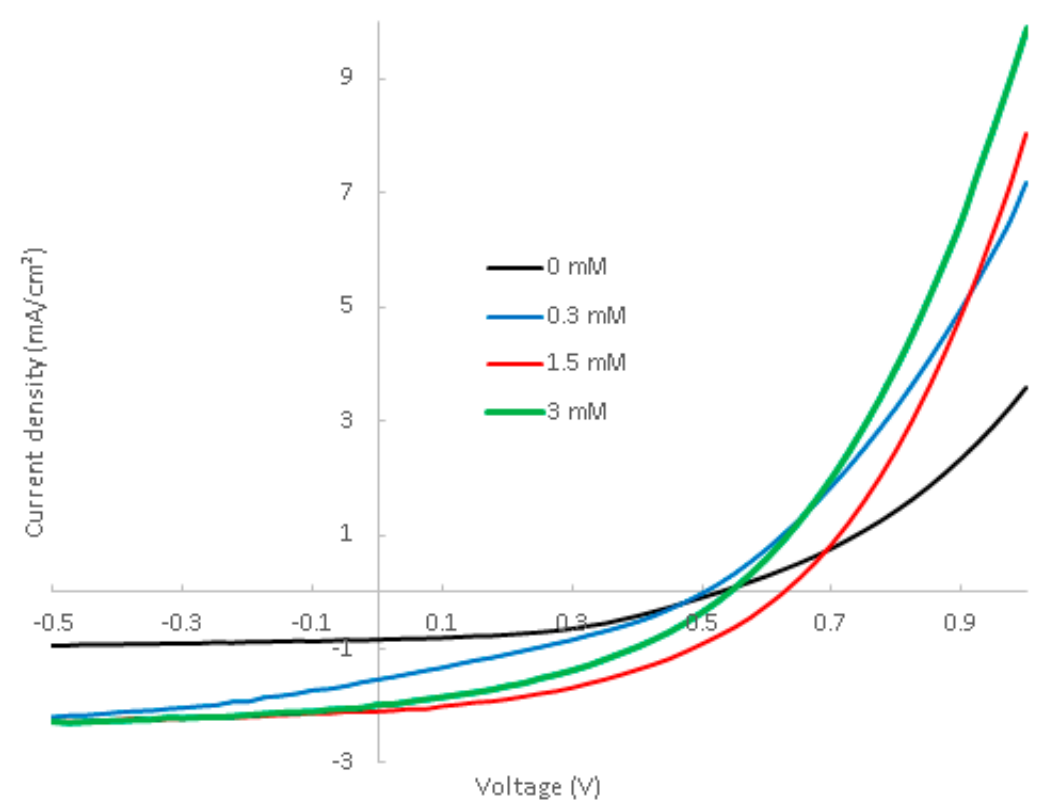

Figure 3. Current-voltage characteristics of solid-state dye sensitized solar cells (ssDSSCs) sensitized with dye $\mathbf{M} 2$ depending on the co-adsorbent concentration.

The performance obtained for the reference cell is in agreement with those previously reported in the literature $[45,46]$. Modest photovoltaic performances are observed for dye M2 compared to liquid DSSCs, where the short-circuit current density $\left(J_{S C}\right)$ was found to be reduced by a factor of about 10. This finding could mainly be attributed to the reduction in the electrode thickness for solid-state devices, leading to a lower light harvesting efficiency of the active layer. The devices where the $\mathrm{TiO}_{2}$ electrode was sensitized with the dye M2 alone, gave photovoltaic efficiencies of $0.19 \%$. When M2 was combined with CDCA, the PCE increased up to $0.56 \%$ for the $1: 5$ molar ratio. Further increase in 
co-adsorbent to the 1:10 molar ratio caused a decrease in efficiency $(\eta=0.42 \%)$, attributed to the dye loading reduction.

Table 2. Photovoltaic parameters of ssDSSCs sensitized with M2 or D102 under simulated solar emission $\left(100 \mathrm{~mW} \cdot \mathrm{cm}^{-2}, \mathrm{AM} 1.5 \mathrm{G}\right)$ as a function of the co-adsorbent concentration: short-circuit current density $\left(J_{S C}\right)$, open-circuit voltage $\left(\mathrm{V}_{\mathrm{OC}}\right)$; fill factor $(\mathrm{FF})$, and power conversion efficiency $(\eta)$.

\begin{tabular}{cccccc}
\hline Concentration & $\mathbf{V}_{\mathbf{O C}}(\mathbf{V})$ & $J_{\text {SC }}\left(\mathbf{m A} \cdot \mathbf{c m}^{-2}\right)$ & FF & $\boldsymbol{\eta}$ & Best $\boldsymbol{\eta}$ \\
\hline $0 \mathrm{mM}$ & $0.54 \pm 0.01$ & $0.73 \pm 0.10$ & $47 \pm 4$ & $0.18 \pm 0.01$ & 0.19 \\
$0.3 \mathrm{mM}$ & $0.52 \pm 0.02$ & $1.27 \pm 0.24$ & $36 \pm 3$ & $0.23 \pm 0.02$ & 0.25 \\
$1.5 \mathrm{mM}$ & $0.65 \pm 0.03$ & $1.73 \pm 0.19$ & $48 \pm 5$ & $0.53 \pm 0.03$ & 0.56 \\
$3 \mathrm{mM}$ & $0.56 \pm 0.02$ & $1.96 \pm 0.24$ & $40 \pm 0$ & $0.39 \pm 0.03$ & 0.42 \\
D102 & $0.76 \pm 0.01$ & $10.01 \pm 0.19$ & $49 \pm 3$ & $3.73 \pm 0.26$ & 3.99 \\
\hline
\end{tabular}

The incident photon-to-current efficiency (IPCE) recorded for the above mentioned ssDSSCs indicates that the photocurrent response of M2-based DSSC impregnated with $1.5 \mathrm{mM}$ of co-adsorbent exceeds $4 \%$ for the last $Q$ band at $675 \mathrm{~nm}$, which is higher than the response without co-adsorbent ( $2 \%$ at the same wavelength; Figure 4 ). The estimated photocurrent, obtained by integrating the IPCE spectra over the AM1.5G solar spectrum, was consistent with the photocurrent measured under solar simulator and reported in Table 2. Adding $1.5 \mathrm{mM}$ of co-adsorbent for the impregnation enabled to double the current density value from 0.60 to $1.30 \mathrm{~mA} \cdot \mathrm{cm}^{-2}\left(0.73 \mathrm{vs} .1 .73 \mathrm{~mA} \cdot \mathrm{cm}^{-2}\right.$ in Table 2 , respectively). The increased quantum yield was ascribed to the reduction of dye aggregation in the presence of CDCA as co-adsorbent, which minimized the intermolecular energy transfer and increased the electron injection efficiency. This effect compensated the loss of light harvesting caused by the lower dye content of the $\mathrm{TiO}_{2}$ photoanode with CDCA as co-adsorbent and led to the improvement of the current density. Based on this result, a concentration of $1.5 \mathrm{mM}$ of co-adsorbent was chosen for the preparation of ssDSSCs since it offered the best compromise between light harvesting and power conversion efficiency.

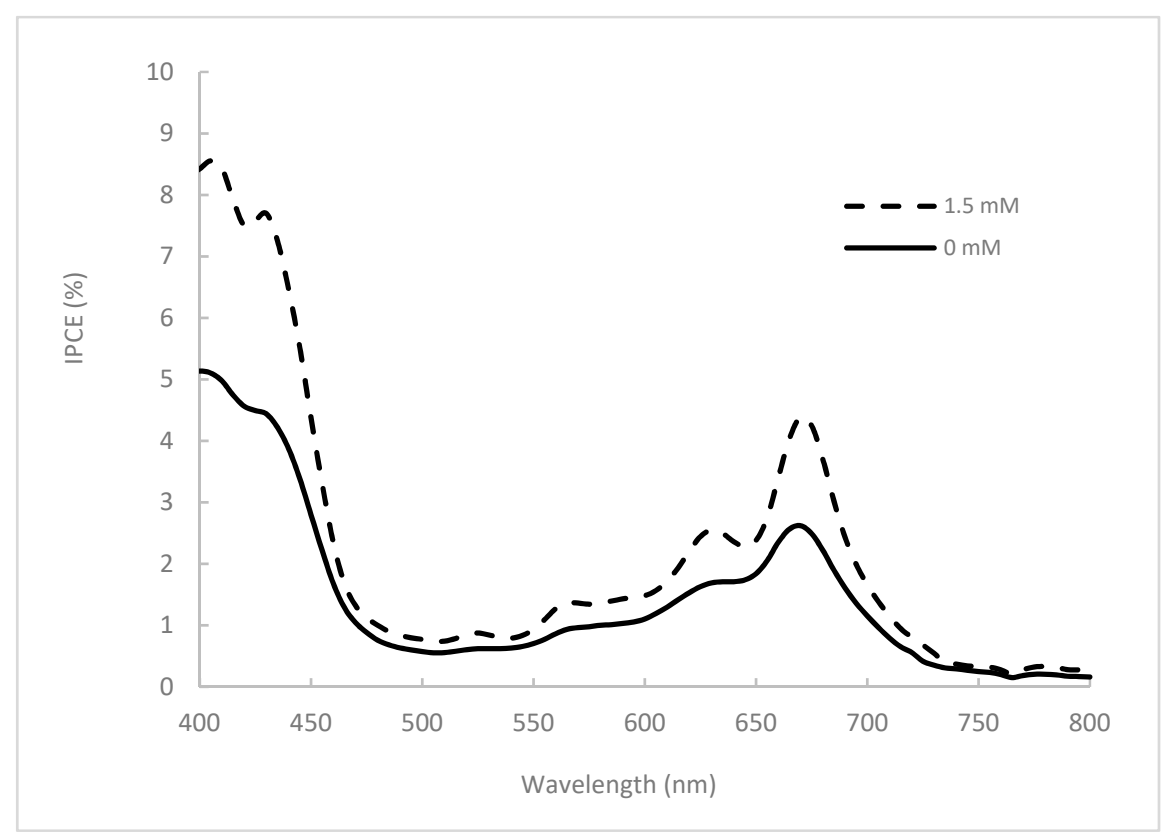

Figure 4. Incident photon-to-current efficiency (IPCE) spectra of all-solid state DSSCs sensitized with M2 in the presence/absence of co-adsorbent. 


\subsubsection{Photovoltaic Measurements for the Other Chlorin Derivatives}

Figure 5 shows the J-V characteristics of the ssDSSCs prepared from dyes M1 to M6 (0.3 mM in THF) and CDCA co-adsorbent (1.5 mM in THF). The corresponding photovoltaic data are listed in Table 3.

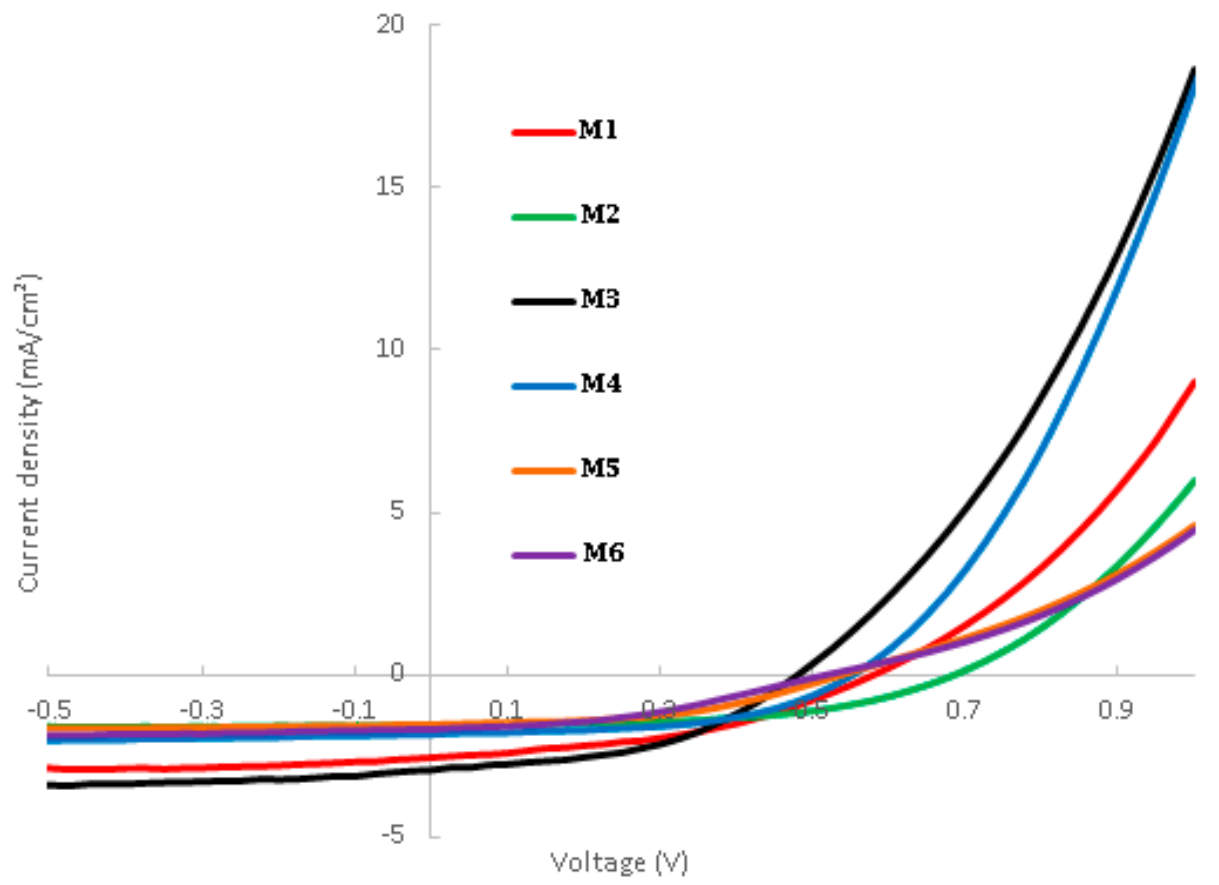

Figure 5. Current-voltage characteristics of ssDSSCs sensitized with chlorins M1-M6 under illumination.

Table 3. Photovoltaic parameters of ssDSSCs sensitized with chlorins M1-M6 and D102 under simulated solar emission (100 $\left.\mathrm{mW} \cdot \mathrm{cm}^{-2}, \mathrm{AM} 1.5 \mathrm{G}\right)$ : short-circuit current density $\left(J_{\mathrm{SC}}\right)$, open-circuit voltage $\left(\mathrm{V}_{\mathrm{OC}}\right)$, fill factor $(\mathrm{FF})$, and power conversion efficiency $(\eta)$.

\begin{tabular}{cccccc}
\hline Compound & V $_{\text {OC }}(\mathbf{V})$ & $J_{\text {SC }}\left(\mathbf{m A} \cdot \mathbf{c m}^{-2}\right)$ & FF & $\boldsymbol{\eta}$ & Best $\boldsymbol{\eta}$ \\
\hline M1 & $0.54 \pm 0.03$ & $1.99 \pm 0.27$ & $42 \pm 3$ & $0.45 \pm 0.15$ & 0.60 \\
M2 & $0.65 \pm 0.03$ & $1.73 \pm 0.19$ & $48 \pm 5$ & $0.53 \pm 0.03$ & 0.56 \\
M3 & $0.53 \pm 0.05$ & $2.31 \pm 0.63$ & $46 \pm 4$ & $0.55 \pm 0.12$ & 0.67 \\
M4 & $0.54 \pm 0.04$ & $1.62 \pm 0.20$ & $49 \pm 4$ & $0.43 \pm 0.08$ & 0.51 \\
M5 & $0.54 \pm 0.02$ & $1.16 \pm 0.12$ & $54 \pm 6$ & $0.34 \pm 0.05$ & 0.39 \\
M6 & $0.53 \pm 0.02$ & $0.97 \pm 0.15$ & $52 \pm 4$ & $0.26 \pm 0.07$ & 0.33 \\
\hline
\end{tabular}

Compared to the D102 performances, those obtained with chlorin dyes were low (Table 3). Nevertheless, only a few publications have described the fabrication of ssDSSCs with chlorophyll derivatives and the values obtained here are in line with those reported [31]. They were even better than the performances obtained in some liquid-DSSCs with other chlorophyll derivatives [47-50]. ssDSSCs based on dye M3 gave the highest PCE (0.67\%) due to the highest short-circuit current (JSC), while the open-circuit photovoltage $\left(\mathrm{V}_{\mathrm{OC}}\right)$ and fill factors $(\mathrm{FF})$ were found to be similar to other chlorin dyes, except for M2, which showed the highest $\mathrm{V}_{\mathrm{OC}}$ value. In terms of grafting groups, the PCE values for ssDSSCs based on chlorin dyes exceed $0.26 \%$ in the following order: acrylic acid $>$ alkyl acid $>$ cyanoacrylic acid. The introduction of cyano electron-withdrawing groups in chlorins M5-M6 indeed strongly decreased the $J_{\mathrm{SC}}$ values, resulting in the ssDSSCs with the lower performances. This trend has been already observed when such chlorin dyes were used in liquid DSSCs [51]. Nevertheless, the difference observed in ssDSSCs was not as dramatic as in liquid DSSCs. For instance, the presence 
of cyano groups on the free base chlorin M3 drastically decreased the PCE in liquid DSSCs by around $75 \%$ while the decrease represents only $37 \%$ in ssDSSCs.

\subsubsection{Recombination Kinetics}

To examine the recombination kinetics of chlorin-based ssDSSCs, transient photovoltage decay measurements (TPV) measurements were carried out and compared to D102. Since the porous electrode and the anchoring groups of the dyes are quite similar (i.e., same fabrication process and only one carboxylic anchoring function on each dye), TPV measurements reflect the direct influence of the dye on the $\mathrm{TiO}_{2} /$ dye/spiro-OMeTAD interface. The observed differences in recombination kinetics could mainly be attributed to the chemical nature and/or steric conformation of the dye at the $\mathrm{TiO}_{2}$ surface as well as the contribution from the dye/spiro-OMeTAD interface. The observed difference in slope between D102 and the chlorin dye sensitizers indicates that different recombination mechanisms took place in ssDSSCs sensitized with these compounds (Figure 6). The recombinations for chlorin-sensitized solar cells appeared to be faster than that with D102, thus leading to a $V_{O C}$ loss. This result was coherent with the photovoltaic parameters obtained under illumination. Indeed, chlorin-based ssDSSCs exhibited $\mathrm{V}_{\mathrm{OC}}$ values around $550 \mathrm{mV}$, except for $\mathbf{M} 2$ whereas that based on the D102 dye sensitizer led to a $\mathrm{V}_{\mathrm{OC}}$ of $760 \mathrm{mV}$.

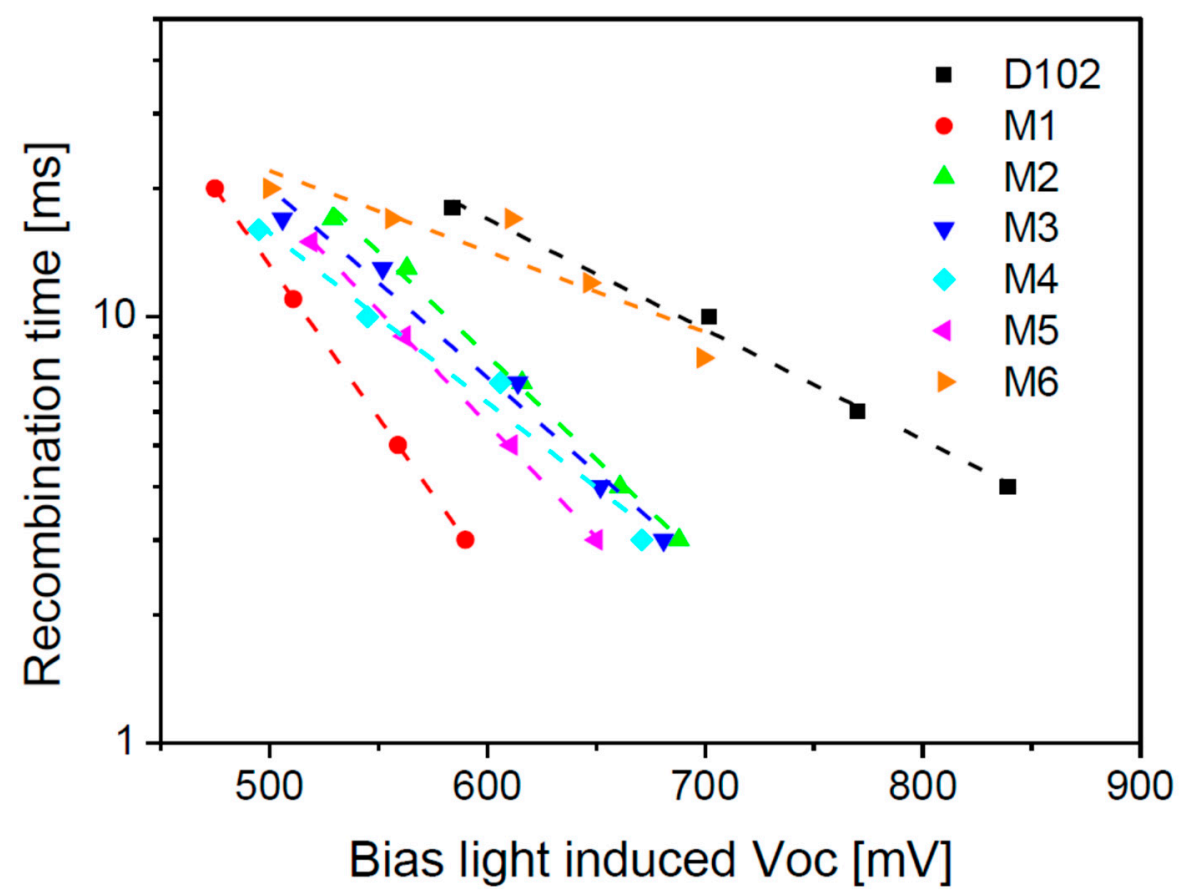

Figure 6. Electron recombination lifetime as a function of Voc in chlorin- and D102 based ssDSSCs.

Besides, chlorin dyes M3 and M5 show an enhanced electron lifetime in comparison with the M1 analog. Electron lifetime associated with dye M3 was also slightly larger than that of dye M5, which suggests acrylic acid anchoring group was more favorable than cyanoacrylic acid anchoring group to decrease the charge recombination at the $\mathrm{TiO}_{2} /$ electrolyte interface. However, the performances of ssDSSC s based on M5 were lower than those based on M1. Since the dye M1 contains a non-conjugated anchoring group, $\mathbf{M 1}$ may lie rather flat on the $\mathrm{TiO}_{2}$ surface due the larger flexibility of the alkyl spacer, whereas the more rigid conjugated spacer of $\mathbf{M} 3$ and M5 probably favors tilted or up-right adsorption. Finally, the influence of the zinc metal center was more difficult to interpret: on one hand, M2 presented a significant increase in electron lifetime compared to M1; on the other hand, M3 and M4 were in the same range. These findings were coherent with the photovoltaic parameters 
obtained under illumination. As discussed above, M2 exhibited a higher Voc than M1 while the Voc was approximately the same for M3 and M4.

\subsection{DFT Calculations}

To elucidate the relationship between the nature of the anchoring group and the photovoltaic performances observed, density functional theory (DFT) calculations were performed. The calculations show that all the LUMO $+\mathrm{n}$ orbitals had a significant contribution from the acrylic group for $\mathbf{M} 4$ and from the cyanoacrylic acid group for M6 while only the LUMO + 3 orbital covered the alkyl carboxylic group for M2 (Figure 7). This is critically important since the orbital overlap between the LUMO $+\mathrm{n}$ of the dye and the $\mathrm{TiO}_{2}$ conduction band edge should be as large as possible in order to maximize the electron transfer probability. M4 and M6 dyes exhibited similar $\pi$-electron systems leading to similar electron density on the $\pi$-conjugated anchoring group for LUMO, LUMO +1 , and LUMO +2 orbitals.

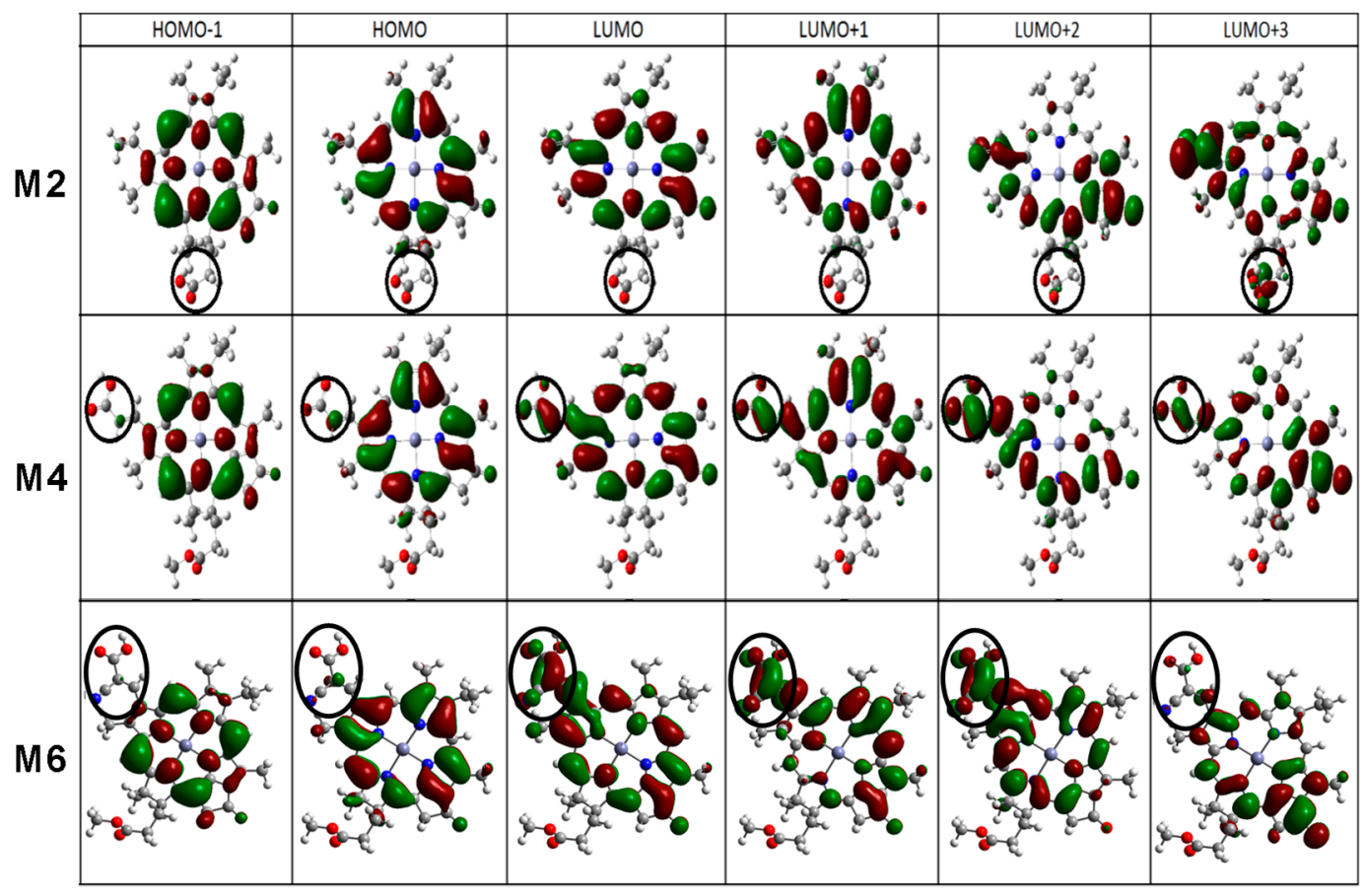

Figure 7. HOMO-1, HOMO, LUMO, LUMO + 1, LUMO + 2, and LUMO + 3 molecular orbitals for M2 (top) and M4 (middle) and M6 (bottom) dyes. The anchoring groups are circled in black.

However, introducing the electron-withdrawing cyano group on the acrylic acid anchoring results in a strong stabilization of the unoccupied orbitals (Figure 8). Indeed, the M6 LUMO moved down below the $\mathrm{TiO}_{2}$ conduction band edge energy level, no longer allowing exergonic electron injection to $\mathrm{TiO}_{2}$ upon (HOMO $\rightarrow$ LUMO) optical transition, thus, explaining the decrease in PCE of M6 compared to M4. The energy levels of HOMO and LUMO of M2, M4, and M6 dyes are in the same range as those previously reported in the literature $[31,33,52]$. 


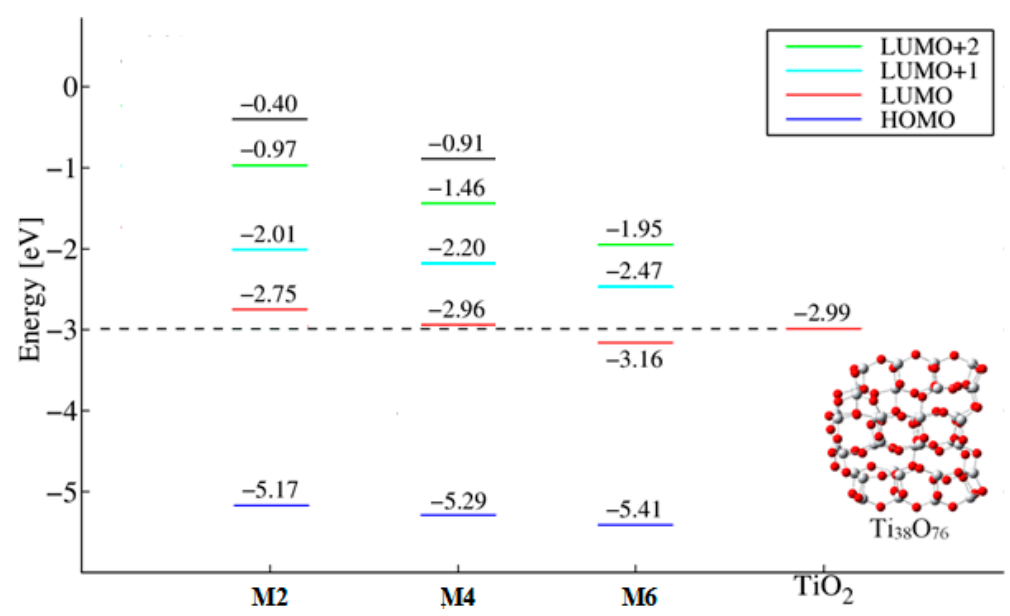

Figure 8. LUMO, LUMO + 1, and LUMO + 2 energy levels of chlorin dyes M2, M4, and M6. The values for the conduction band edge of the semiconductor calculated from a $\mathrm{Ti}_{38} \mathrm{O}_{76}$ cluster is added for comparison (dashed line).

\subsection{Dye Adsorption}

To get insight into the relationship between the observed performances and the dye structure, the dye adsorption of free-base chlorins M1, M3, and M5 was investigated by the use of electron paramagnetic resonance spectroscopy (EPR). This experimental technique allowed us to compare the cells performance with the dye adsorption on the $\mathrm{TiO}_{2}$ thanks to a paramagnetic radical probe 4-carboxy TEMPO (coded as 4C-T). This molecule grafts onto the $\mathrm{TiO}_{2}$ surface without perturbing the system and is able to monitor its molecular surrounding through spin-spin interactions. As described more in depth elsewhere [53], the main parameters extracted from the spectra are as follows: (i) $A_{i i}$, which is the component of the hyperfine coupling tensor between the electronic and nuclear spin that provides a measurement of the probe environmental polarity; (ii) the correlation time for the radical rotational diffusion motion, $\tau$, that is related to the radical environmental microviscosity, which, in turn, increases due to interactions between the radical and its environment; (iii) the intrinsic line width, its increment in slow motion conditions being due to dipole-dipole spin-spin interactions (through this parameter, interactive close sites can be identified); and (iv) the Heisenberg exchange frequency, Wex, which increases when radicals swap each other the unpaired electrons due to collisions in a fluid medium (this parameter is related to a high radical local concentration on the $\mathrm{TiO}_{2}$ surface). In many cases, the EPR spectra are constituted by two well-identifiable components characterized by probes at different polarity and mobility. In order to extract the two components and to evaluate the relative percentages, experimental spectra were subtracted from each other and then the components were separately simulated and doubly integrated to evaluate the relative percentages. If subtraction of experimental spectra cannot be performed, one component is simulated and the other one is determined by subtraction of the simulated spectrum from the total one. Afterwards, the second component is also simulated. The accuracy for all the parameters in the EPR analysis was between $2 \%$ and $3 \%$, based on the fitting between the experimental and the computed line shapes, slightly increasing if line broadening occurs.

Figure 9 shows the EPR spectra obtained for DSSCs built with the different dyes M1, M3, and M5 and containing the spin probe 4C-T. These spectra were considered good if reproducible at least for three different cells built in the same experimental conditions. 


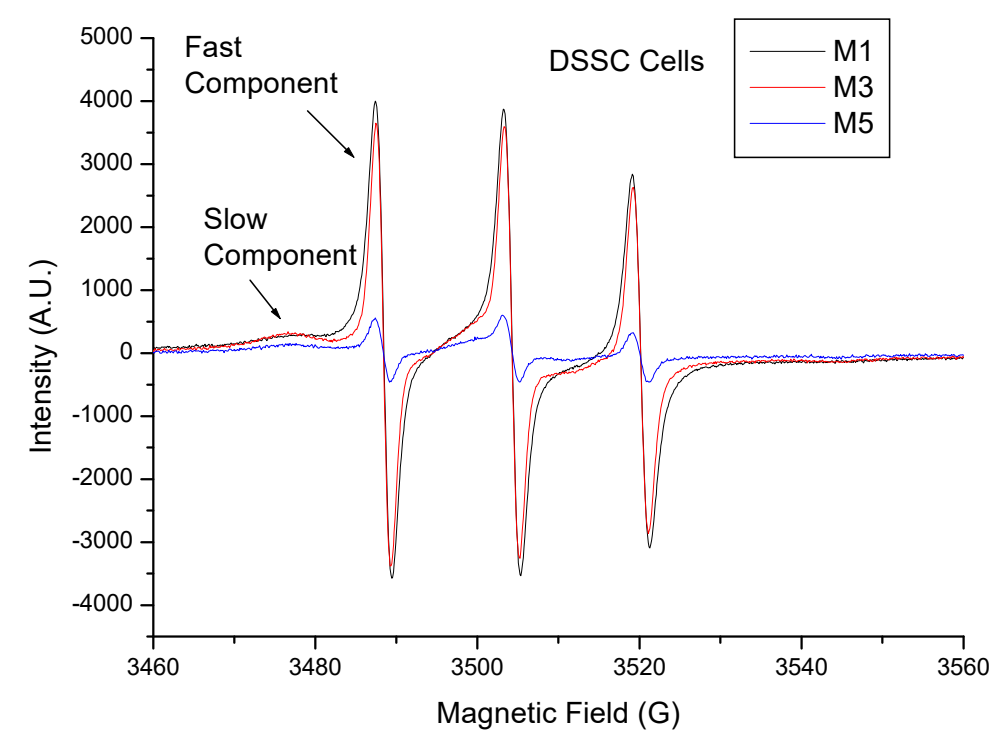

Figure 9. Electron paramagnetic resonance spectroscopy (EPR) spectra of DSSCs sensitized with the chlorine dyes M1 (black line), M3 (red line) and M5 (blue line). The relative fast component and free component of the spectra are shown in the graph.

From Figure 9, we could determine that: (i) the intensity significantly decreased for DSSC-M5 with respect to the other DSSC-dyes. The intensity was evaluated by double integrating the spectra (Table 1). We also noticed that the intensity largely decreased when compared to devices containing only the spin probe (results not shown) and (ii) the spectra were constituted by two components whose main features are indicated in the figure. These two components were extracted and quantified (Table 4).

Table 4. Values of the total intensity and the relative percentage for the slow and fast component.

\begin{tabular}{cccc}
\hline Dye & $\begin{array}{c}\text { Total Intensity (Integrated; } \\
\text { Arbitrary Unit) }\end{array}$ & $\begin{array}{c}\text { \% of Slow Component } \\
\text { with Respect to the Fast }\end{array}$ & $\begin{array}{c}\text { \% of Slow Component with } \\
\text { Respect to the Total }\end{array}$ \\
\hline M1 & 64 & 5 & 3 \\
M3 & 52 & 35 & 18 \\
M5 & 14 & 69 & 10 \\
\hline
\end{tabular}

Each component was then computed as shown in Figure 10 for the different cells. The figure also shows the main parameters used for the computation, which are the $<A>$ value $\left(=\left(A_{x x}+A_{y y}+A_{z z}\right) / 3\right)$ measuring the polarity, the correlation time for the rotational motion, $\tau$, measuring the interactions on the basis of the slowing down of mobility, and the line width, measuring the local concentration of the radicals. Based on the correlation time for the rotational motion, $\tau$, obtained from the computations, the two components were termed "fast" and "slow", since they originated from spin probes quite free to move at the interface and interacting with the $\mathrm{TiO}_{2}$ surface, respectively. 

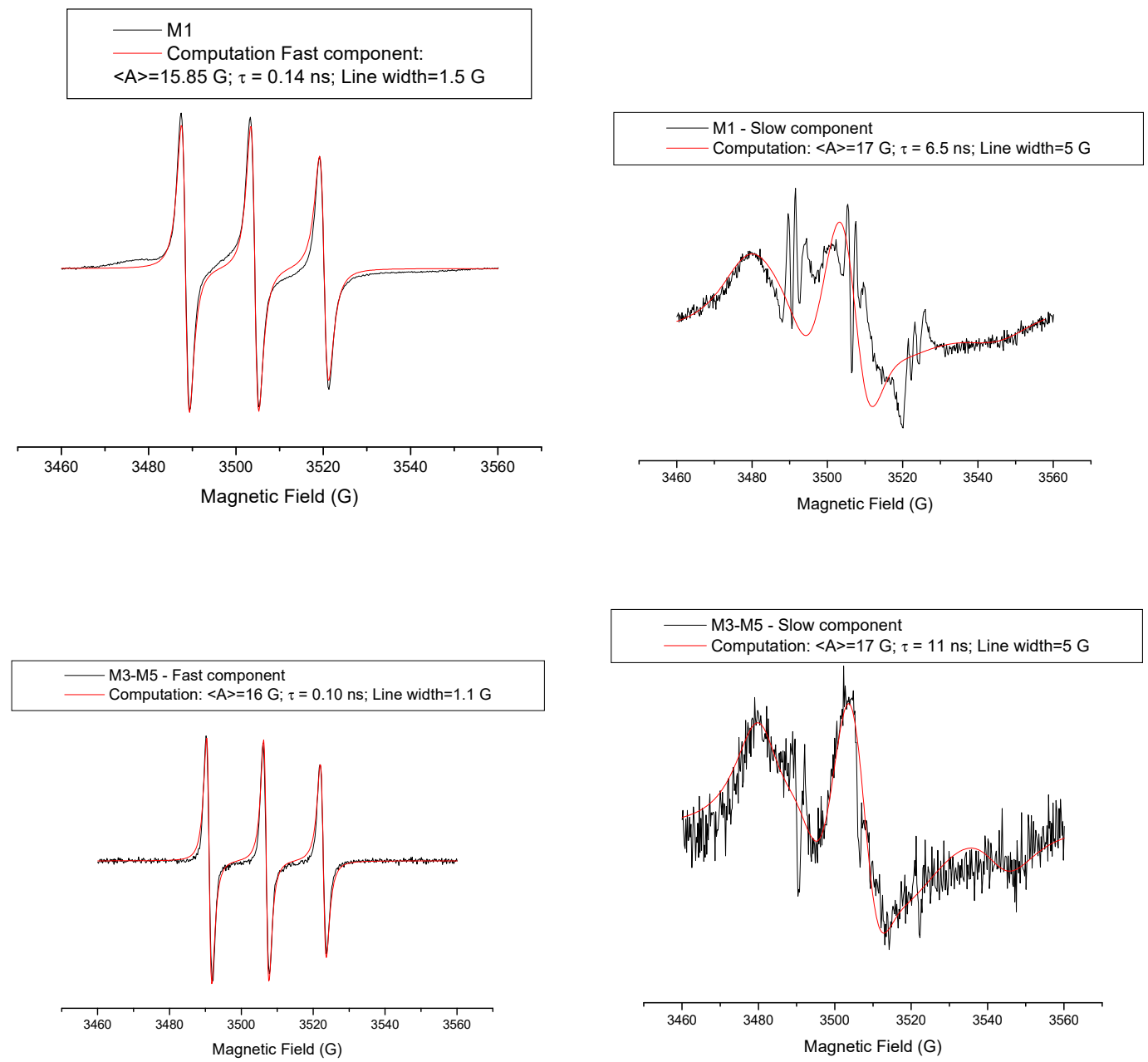

Figure 10. Experimental and computed spectra (extracted slow and fast component) for the probe 4C-T interacting with the dyes M1, M3, and M5.

The low intensity of the spectrum of DSSC-M5 if compared to the other DSSCs clarified the behavior of these dyes: M5 was poorly adsorbed, but the probes and M5 preferentially interacted with the surface (slow component) and only a small amount of dyes remained at the interface (free component). In other words, the total amount of adsorbed dye M5 as well as the amount of interacting probes + M5-dyes were small. That amount was obviously smaller than the amount of probes and dye M3 adsorbed at the $\mathrm{TiO}_{2}$ surface. Considering the slow component, it was the same for M5 and M3 corresponding to strongly interacting dyes at polar, quite close sites. Conversely, the fast component shows a high mobility and the environment was less polar than that of the slow component. These results also explained why dye M3 exhibited better performances than M5. M1 was the less interacting dye, not only marked by the lowest percentage of slow (interacting) component compared to the other dyes, but also because the slow component is slower (lower $\tau$ ) in comparison with the other dyes. It is also interesting to note that the fast component for M1 shows a slightly lower mobility, lower polarity and higher line width compared to the fast component from the other dyes. This indicates a higher local concentration of $\mathbf{M} 1$ dyes in solution, in line with a lower adsorption at the $\mathrm{TiO}_{2}$ surface.

\section{Materials and Methods}

\subsection{Instrumentation and Methods}

Spirulina powder was provided from Phyco-Biotech (Montpellier, France). Titania paste (99\% anatase), titanium(IV) chloride (99,9\%), chenodeoxycholic acid (96\%), bis(trifluoromethane)sulfonimide 
lithium salt (99\%), 4-tert-butylpyridine (98\%) were purchased from Sigma-Aldrich Chemie S.a.r.l. (Saint-Quentin Fallavie, France). Spiro-OMeTAD and FTO-coated conducting glass substrates were purchased from Solaronix SA (Aubonne, Switzerland). Reactions were performed under argon using oven-dried glassware and Schlenk techniques. Dry solvents were obtained by using a solvent purification system, PureSolve MD5 purchased from Inert Technology (Amesbury, MA, USA). ${ }^{1} \mathrm{H}$ and ${ }^{13} \mathrm{C}\left\{{ }^{1} \mathrm{H}\right\}$ NMR spectra were recorded either on a Bruker Avance-300, 400, or 600 spectrometers (Bruker, Billerica, MA, USA) for each synthetic intermediates and were calibrated to tetramethylsilane (TMS) on the basis of the relative chemical shift of the solvent as an internal standard. Chemical shifts $(\delta)$ are expressed in parts per million (ppm) and coupling constants $(J)$ are expressed in Hertz. Abbreviations used for ${ }^{1} \mathrm{H}-\mathrm{NMR}$ spectra are as follow: s singlet, $\mathrm{d}$ doublet, and m multiplet. Mass spectra (MS) were recorded on MicroTOF QII $t$ and RAPIFLEX instruments (Bruker France SAS, Marne la Vallée, France) in the positive mode for ESI and MALDI-ToF, respectively. UV-Visible absorption spectra were obtained at room temperature on a Shimadzu UV2401 PC (Shimadzu Corporation, Kyoto, Japan) and on a SAFAS D.E.S. PC UV/Vis scanning spectrometers (Safas, Monaco).

\subsection{Synthesis of Dyes $\mathbf{M 1}, \mathbf{M} 3$, and $\mathbf{M} 5$}

Methyl pheophorbide- $a$ [34], methyl pyropheophorbide- $a$ (MPPa) [34], methyl pyropheophorbide- $d$ (MPPd) [35], M1 [28], M2 [54], M3 [28], M4 [55], M5 [56], and M6 [55] were synthesized as reported in the literature (see Scheme 1 for the synthetic route).

M1: Methyl pyropheophorbide- $a(150 \mathrm{mg}, 2.74 \mathrm{mmol})$ was dissolved in acetone $(15 \mathrm{~mL})$ and concentrated hydrochloric acid $(\mathrm{HCl} 37 \%, 5 \mathrm{~mL})$ was added slowly. After 30 min under stirring, the mixture was poured into water and extracted with $\mathrm{CH}_{2} \mathrm{Cl}_{2}$. The organic layer was then washed with a saturated solution of $\mathrm{NaHCO}_{3}$ and water until neutrality. The organic layer was dried over $\mathrm{MgSO}_{4}$, filtered, and concentrated under reduced pressure. The obtained solid was then recrystallized from a $\mathrm{CH}_{2} \mathrm{Cl}_{2} / n$-pentane mixture to give the title compound as a dark solid (129 mg, 88\%). ${ }^{1} \mathrm{H}-\mathrm{NMR}$ $\left(300 \mathrm{MHz}, \mathrm{CDCl}_{3}\right): \delta=9.50,9.39,8.58(\mathrm{~s}$, each $1 \mathrm{H}, 5-, 10-$, and, $20-\mathrm{H}), 7.98\left(\mathrm{dd},{ }^{3} J_{\mathrm{H}-\mathrm{H}}=17.8,11.5 \mathrm{~Hz}, 1 \mathrm{H}\right.$, $\left.3^{1}-\mathrm{H}\right), 6.22\left(\mathrm{~m}, 2 \mathrm{H}, 3^{2}-\mathrm{CH}\right), 5.18\left(\mathrm{~m}, 2 \mathrm{H}, 13^{2}-\mathrm{CH}_{2}\right), 4.49,4.41(\mathrm{~m}$, each $1 \mathrm{H}, 17-$ and $18-\mathrm{H}), 3.64(\mathrm{~m}, 3 \mathrm{H}$, $8^{1}-\mathrm{CH}_{2}$ and $\left.12^{1}-\mathrm{CH}_{3}\right), 3.40\left(2-\mathrm{CH}_{3}\right), 3.23\left(\mathrm{~s}, 3 \mathrm{H}, 7-\mathrm{CH}_{3}\right), 2.70-2.30\left(\mathrm{~m}, 4 \mathrm{H}, 17^{1}\right.$ and $\left.17^{2}-\mathrm{CH}_{2}\right), 1.82(\mathrm{~d}$, $\left.{ }^{3} J_{\mathrm{H}-\mathrm{H}}=7.1 \mathrm{~Hz}, 3 \mathrm{H}, 18^{1}-\mathrm{CH}_{3}\right), 1.68\left(\mathrm{t},{ }^{3} \mathrm{~J}_{\mathrm{H}-\mathrm{H}}=7.5 \mathrm{~Hz}, 4 \mathrm{H}, 8^{2}-\mathrm{CH}_{3}\right) \mathrm{ppm} .{ }^{13} \mathrm{C}\left\{{ }^{1} \mathrm{H}\right\} \mathrm{NMR}(101 \mathrm{MHz}$, pyridine- $\left.d_{5}\right): \delta=196.0,176.1,172.8,162.4,155.7,151.7,149.5,145.8,142.0,138.7,137.0,136.7,136.3$, $132.5,131.7,130.0,128.9,123.0,107.4,104.9,97.9,94.5,52.7,50.7,48.8,32.3,31.1,23.7,20.0,18.1,12.5$, 12.3, $11.6 \mathrm{ppm}$. Maldi-ToF MS: calcd for $\mathrm{C}_{33} \mathrm{H}_{34} \mathrm{~N}_{4} \mathrm{O}_{3} \mathrm{~m} / z$ 534.263, found 534.290. UV-Visible (THF): $\lambda_{\max }(\varepsilon) 414$ (77500), 507 (8200), 536 (6600), 310 (5300), 668 (33600) nm.

M3: Chlorin-1 (117 mg, $0.180 \mathrm{mmol})$ was dissolved in trifluoroacetic acid (6.5 mL). The green solution was stirred for $3 \mathrm{~h}$ at room temperature and then, poured into water. The organic layer was extracted with $\mathrm{CH}_{2} \mathrm{Cl}_{2}$, dried over $\mathrm{MgSO}_{4}$, filtered and concentrated under reduced pressure. The brown residue was purified by column chromatography on silica gel $\left(\mathrm{CH}_{2} \mathrm{Cl}_{2} / \mathrm{MeOH}, 19: 1\right)$ to give the title compound as a black solid $(68 \mathrm{mg}, 64 \%) .{ }^{1} \mathrm{H}-\mathrm{NMR}\left(600 \mathrm{MHz}, \mathrm{CDCl}_{3} /\right.$ pyridine- $\left.d_{5}\right): \delta=9.41$ $(\mathrm{s}, 1 \mathrm{H}, 10-\mathrm{H}), 9.37(\mathrm{~s}, 1 \mathrm{H}, 5-\mathrm{H}), 9.03\left(\mathrm{~d}, 1 \mathrm{H},{ }^{3} J_{\mathrm{H}-\mathrm{H}}=16.1 \mathrm{~Hz}, 3^{2}-\mathrm{CH}\right), 8.56(\mathrm{~s}, 1 \mathrm{H}, 20-\mathrm{H}), 7.04(\mathrm{~d}, 1 \mathrm{H}$, $\left.{ }^{3} J_{\mathrm{H}-\mathrm{H}}=16.1 \mathrm{~Hz}, 3^{1}-\mathrm{CH}\right), 5.17,5.01\left(\mathrm{~d}\right.$, each $\left.1 \mathrm{H},{ }^{3} J_{\mathrm{H}-\mathrm{H}}=19.2 \mathrm{~Hz}, 13^{2}-\mathrm{CH}_{2}\right), 4.40,4.20(\mathrm{~m}$, each $1 \mathrm{H}, 17-$, and $18-\mathrm{H}), 3.54,3.48,3.36,3.10$ (s, each $3 \mathrm{H}, 2^{1}-, 7^{1}-$, and $\left.12^{1}-\mathrm{CH}_{3}, 17^{2}-\mathrm{COOMe}\right), 3.53\left(\mathrm{~m}, 2 \mathrm{H}, 8^{1}-\mathrm{CH}_{2}\right)$, 2.60, $2.50\left(\mathrm{~m}\right.$, each $\left.1 \mathrm{H}, 17^{2}-\mathrm{CH}_{2}\right), 2.20\left(\mathrm{~m}, 2 \mathrm{H}, 17^{1}-\mathrm{CH}_{2}\right), 1.72\left(\mathrm{~d}, 3 \mathrm{H}, J=7.5 \mathrm{~Hz}, 18^{1}-\mathrm{CH}_{3}\right), 1.57(\mathrm{t}, 3 \mathrm{H}$, $\left.{ }^{3} \mathrm{~J}_{\mathrm{H}-\mathrm{H}}=7.7 \mathrm{~Hz}, 8^{2}-\mathrm{CH}_{3}\right), 0.08,-1.97(\mathrm{~s}$, each $\left.1 \mathrm{H}, \mathrm{NH}) \mathrm{ppm} .{ }^{13} \mathrm{C}^{1}{ }^{1} \mathrm{H}\right\} \mathrm{NMR}\left(151 \mathrm{MHz}, \mathrm{CDCl}_{3} / \mathrm{Pyr}\right)$ : $\delta=195.6,173.1,170.7,169.1,160.7,154.7,151.0,149.4,148.5,144.7,140.3,138.1,136.3,135.5,135.4,133.5$, $131.9,130.7,128.5,126.3,123.2,106.2,103.6,96.7,93.5,51.6,51.3,49.6,47.8,30.7,29.6,22.9,19.2,17.2$, 12.4, 11.8, 11.0 ppm. ESI-ToF HR-MS: calcd for $\mathrm{C}_{35} \mathrm{H}_{36} \mathrm{~N}_{4} \mathrm{O}_{5}[\mathrm{M}+\mathrm{H}]^{+} m / z$ 593.2841, found 593.2845. UV-Visible (THF): $\lambda_{\max }(\varepsilon) 417$ (33000), 513 (4600), 545 (3600), 621 (2700), 681 (17000) nm.

M5: To a solution of methyl pyropheophorbide- $d(200 \mathrm{mg}, 0.363 \mathrm{mmol})$ and cyanoacetic acid $(6.18 \mathrm{~g}, 72.6 \mathrm{mmol})$ in THF $(20 \mathrm{~mL})$ was added ammonium acetate $(2.80 \mathrm{~g}, 36.3 \mathrm{mmol})$. The mixture was refluxed for $1 \mathrm{~h}$, poured into water and extracted with $\mathrm{CH}_{2} \mathrm{Cl}_{2}$. The extract was dried over $\mathrm{MgSO}_{4}$, 
filtered, and concentrated under vacuum. The residue was then recrystallized from a $\mathrm{CH}_{2} \mathrm{Cl}_{2} / n$-pentane mixture to give the title compound as a dark solid ( $145 \mathrm{mg}, 65 \%) .{ }^{1} \mathrm{H}$ NMR $\left(400 \mathrm{MHz}, \mathrm{DMSO}-d_{6}\right)$ : $\delta=9.62,9.32,9.13,8.62$ (s, each $1 \mathrm{H}, 5-, 10-$, and $\left.20-\mathrm{H}, 3^{1}-\mathrm{CH}\right), 5.14,5.06\left(\mathrm{~d}\right.$, each $1 \mathrm{H},{ }^{3} J_{\mathrm{H}-\mathrm{H}}=19.9$ $\left.\mathrm{Hz}, 13^{1}-\mathrm{CH}_{2}\right), 5.06,4.54(\mathrm{~m}$, each $1 \mathrm{H}, 17-$, and $18-\mathrm{H}), 3.75\left(\mathrm{~m}, 2 \mathrm{H}, 8^{1}-\mathrm{CH}_{2}\right), 3.59,3.53,3.31,3.23(\mathrm{~s}$, each $3 \mathrm{H}, 2^{1}-, 7^{1}-$, and $\left.12^{1}-\mathrm{CH}_{3}, 17^{2}-\mathrm{COOMe}\right), 2.60,2.24\left(\mathrm{~m}\right.$, each $2 \mathrm{H}, 17^{1}-$, and $\left.17^{2}-\mathrm{CH}_{2}\right), 1.77(\mathrm{~d}$, $\left.\left.3 \mathrm{H},{ }^{3} J_{\mathrm{H}-\mathrm{H}}=7.5 \mathrm{~Hz}, 18^{1}-\mathrm{CH}_{3}\right), 1.67\left(\mathrm{t}, 3 \mathrm{H}, 3 \mathrm{~J}_{\mathrm{H}-\mathrm{H}}=7.7 \mathrm{~Hz}, 8^{2}-\mathrm{CH}_{3}\right) \mathrm{ppm} .{ }^{13} \mathrm{C}^{1} \mathrm{H}\right\} \mathrm{NMR}(101 \mathrm{MHz}$, DMSO- $\left.d_{6}\right): \delta=195.2,176.5,172.9,167.7,163.2,160.1,156.6,152.0,149.8,147.1,145.3,145.0,143.0,142.7$, 137.2, 135.1, 133.1, 132.9, 131.6, 120.5, 119.1, 105.3, 105.1, 98.4, 92.7, 66.4, 66.2, 66.0, 65.7, 65.5, 51.0, 50.1, 47.7, 47.6, 29.9, 29.2, 24.0, 23.8, 23.6, 23.5, 23.4, 23.0, 18.5, 17.2, 13.2, 12.0, 10.4 ppm. ESI-ToF HR-MS: calcd for $\mathrm{C}_{36} \mathrm{H}_{36} \mathrm{~N}_{5} \mathrm{O}_{5}[\mathrm{M}+\mathrm{H}]^{+} \mathrm{m} / z$ 618.2716, found 618.2717. UV-Visible (THF): $\lambda_{\max }(\varepsilon) 409$ (33000), 515 (5000), 550 (4000), 636 (4500), 688 (13000) nm.

\subsection{General Procedure for the Zinc Metalation to Obtain Dyes M2, M4 and M6}

A saturated methanol solution of zinc acetate dihydrate $\left(\mathrm{Zn}(\mathrm{OAc})_{2} 2 \mathrm{H}_{2} \mathrm{O} ; 10 \mathrm{~mL}\right)$ was added to a solution of metal-free chlorin $(50 \mathrm{mg})$ in THF $(50 \mathrm{~mL})$. After stirring overnight, the solution turned from brown to green. The mixture was filtered off and the filtrate was concentrated under vacuum. The crude material was then recrystallized from a $\mathrm{CH}_{2} \mathrm{Cl}_{2} / n$-pentane mixture to afford the desired zinc complex.

M2: (80\%). ${ }^{1} \mathrm{H}-\mathrm{NMR}\left(400 \mathrm{MHz}\right.$, Pyridine- $d_{5}$ ): $\delta=9.84,9.69,8.83$ (each s, each $1 \mathrm{H}, 5-, 10-$, and $20-\mathrm{H}), 8.19\left(\mathrm{dd},{ }^{3} J_{\mathrm{H}-\mathrm{H}}=17.8,11.6 \mathrm{~Hz}, 1 \mathrm{H}, 3^{1}-\mathrm{H}\right), 6.35,6.15\left(\mathrm{~m}\right.$, each $\left.1 \mathrm{H}, 3^{2}-\mathrm{CH}_{2}\right), 5.56,4.61(\mathrm{~m}$, each $\left.1 \mathrm{H}, 13^{2}-\mathrm{CH}_{2}\right), 4.61,4.48(\mathrm{~m}$, each $1 \mathrm{H}, 17-$, and $18-\mathrm{H}), 3.70\left(\mathrm{~m}, 5 \mathrm{H}, 8^{1}-\mathrm{CH}_{2}\right.$, and $\left.12^{1}-\mathrm{CH}_{3}\right), 3.36\left(2^{1}-\mathrm{CH}_{3}\right)$, $3.22\left(\mathrm{~s}, 3 \mathrm{H}, 7^{1}-\mathrm{CH}_{3}\right), 2.93,2.73\left(\mathrm{~m}\right.$, each $2 \mathrm{H}, 17^{1}-$, and $\left.17^{2}-\mathrm{CH}_{2}\right), 1.85\left(\mathrm{~d},{ }^{3} J_{\mathrm{H}-\mathrm{H}}=7.2 \mathrm{~Hz}, 3 \mathrm{H}, 18^{1}-\mathrm{CH}_{3}\right)$,

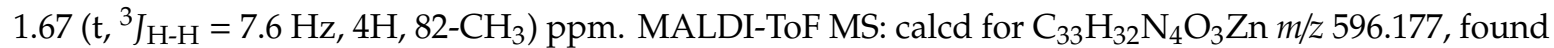
596.180. UV-Visible (THF): $\lambda_{\max }(\varepsilon) 405$ (23800), 427 (39500), 570 (2500), 609 (4400), 657 (22000) nm.

M4: (87\%). ${ }^{1} \mathrm{H}-\mathrm{NMR}\left(400 \mathrm{MHz}, \mathrm{CDCl}_{3} /\right.$ Pyridine- $\left._{5}\right): \delta=9.41(\mathrm{~s}, 1 \mathrm{H}, 10-\mathrm{H}), 9.37(\mathrm{~s}, 1 \mathrm{H}, 5-\mathrm{H}), 9.03$ $\left(\mathrm{d}, 1 \mathrm{H},{ }^{3} J_{\mathrm{H}-\mathrm{H}}=16.1 \mathrm{~Hz}, 3^{2}-\mathrm{CH}\right), 8.56(\mathrm{~s}, 1 \mathrm{H}, 20-\mathrm{H}), 7.04\left(\mathrm{~d}, 1 \mathrm{H},{ }^{3} J_{\mathrm{H}-\mathrm{H}}=16.1 \mathrm{~Hz}, 3^{1}-\mathrm{CH}\right), 5.17,5.01(\mathrm{~d}$, each $\left.1 \mathrm{H},{ }^{3} J_{\mathrm{H}-\mathrm{H}}=19.2 \mathrm{~Hz}, 13^{2}-\mathrm{CH}_{2}\right), 4.40,4.20(\mathrm{~m}$, each $1 \mathrm{H}, 17-$, and $18-\mathrm{H}), 3.54,3.48,3.36,3.10$ (s, each $3 \mathrm{H}, 2^{1}-, 7^{1}-$, and $\left.12^{1}-\mathrm{CH}_{3}, 17^{2}-\mathrm{COOMe}\right), 3.53\left(\mathrm{~m}, 2 \mathrm{H}, 8^{1}-\mathrm{CH}_{2}\right), 2.60,2.50\left(\mathrm{~m}\right.$, each $\left.1 \mathrm{H}, 17^{2}-\mathrm{CH}_{2}\right), 2.20(\mathrm{~m}$, $\left.2 \mathrm{H}, 17^{1}-\mathrm{CH}_{2}\right), 1.72\left(\mathrm{~d}, 3 \mathrm{H},{ }^{3} \mathrm{~J}_{\mathrm{H}-\mathrm{H}}=7.5 \mathrm{~Hz}, 18^{1}-\mathrm{CH}_{3}\right), 1.57\left(\mathrm{t}, 3 \mathrm{H},{ }^{3} \mathrm{~J}_{\mathrm{H}-\mathrm{H}}=7.7 \mathrm{~Hz}, 8^{2}-\mathrm{CH}_{3}\right)$ ppm. ESI-ToF HR-MS: calcd for $\mathrm{C}_{35} \mathrm{H}_{34} \mathrm{~N}_{4} \mathrm{O}_{5} \mathrm{Zn}[\mathrm{M}+\mathrm{H}]^{+} \mathrm{m} / \mathrm{z} 655.1899$, found 655.1901. UV-Visible (THF): $\lambda_{\max }(\varepsilon)$ 414 (37600), 436 (54500), 531 (3500), 576 (4900), 621 (7900), 671 (40100) nm.

M6: (78\%). ${ }^{1} \mathrm{H}-\mathrm{NMR}\left(400 \mathrm{MHz}\right.$, DMSO- $\left.d_{6}\right): \delta=9.62,9.13,8.62$ (s, $1 \mathrm{H}$ each, 5-, 10-, 15-, and 20-H), $9.32\left(\mathrm{~s}, 1 \mathrm{H}, 3^{\prime}-\mathrm{H}\right), 5.14,5.05\left(\mathrm{~d}, 1 \mathrm{H}\right.$ each, $\left.{ }^{3} J_{\mathrm{H}-\mathrm{H}}=19.9 \mathrm{~Hz}, 15^{\prime}-\mathrm{H}\right), 4.55\left(\mathrm{dd}, 1 \mathrm{H},{ }^{3} J_{\mathrm{H}-\mathrm{H}}=7.4,2.5 \mathrm{~Hz}\right.$, $18-\mathrm{H}), 4.28\left(\mathrm{~d}, 1 \mathrm{H},{ }^{3} \mathrm{~J}_{\mathrm{H}-\mathrm{H}}=8.2 \mathrm{~Hz}, 17-\mathrm{H}\right), 3.59,3.53,3.31,3.23(\mathrm{~s}, 3 \mathrm{H}$ each), 2.60, $2.24(\mathrm{~m}, 4 \mathrm{H}), 1.76$ $\left(\mathrm{d}, 3 \mathrm{H},{ }^{3} J_{\mathrm{H}-\mathrm{H}}=7.7 \mathrm{~Hz}, 18^{1}-\mathrm{CH}_{3}\right), 1.65\left(\mathrm{t}, 3 \mathrm{H},{ }^{3} \mathrm{~J}_{\mathrm{H}-\mathrm{H}}=7.6 \mathrm{~Hz}, 8^{2}-\mathrm{CH}_{3}\right) \mathrm{ppm}$. ESI-ToF HR-MS: calcd for $\mathrm{C}_{36} \mathrm{H}_{35} \mathrm{~N}_{5} \mathrm{O}_{5} \mathrm{Zn}[\mathrm{M}+\mathrm{H}]^{+} \mathrm{m} / z$ 680.1852, found 680.1851. UV-Visible (THF): $\lambda_{\max }(\varepsilon) 434$ (48300), 532 (3800), 579 (4700), 625 (7900), $670(36800) \mathrm{nm}$.

\subsection{DFT Calculations}

The ground-state geometry and electronic structure of all dyes and a large $\mathrm{TiO}_{2}$ cluster (representative of the bulk) were obtained at the density functional theory (DFT) level using the B3LYP hybrid functional and the 6-311G $(\mathrm{d}, \mathrm{p})$ basis set. All calculations were performed using Gaussian09 [57]. Solvent effects were taken into account by employing the polarizable continuum model (PCM) using the chloroform solvent as a proxy for the dielectric effects in the DSSC device.

\subsection{Fabrication of Solar Cells}

FTO-coated conducting glass substrates were cleaned by an ultrasonic treatment with water, acetone and isopropanol for $10 \mathrm{~min}$ each before being treated for $5 \mathrm{~min}$ by UV-ozone. A compact layer of $\mathrm{TiO}_{2}$ was deposited by spray-pyrolysis at $450{ }^{\circ} \mathrm{C}$ from a solution of titanium tetra-isopropoxide and acetylacetone in ethanol following by annealing at $450{ }^{\circ} \mathrm{C}$ for $20 \mathrm{~min}$ (Film thickness $200 \mathrm{~nm}$ ). 
A nanoporous $\mathrm{TiO}_{2}$ layer was applied by spin-coating from a solution of a commercial $\mathrm{TiO}_{2}$ paste (DSL 18NRT, Dyesol) in ethanol containing nano-sized anatase particles (Film thickness $1.6 \mu \mathrm{m}$ ). The layers were then gradually annealed from 250 to $500{ }^{\circ} \mathrm{C}$ over $45 \mathrm{~min}$. The substrates were then treated in a $0.02 \mathrm{M} \mathrm{TiCl}_{4}$ aqueous solution for $2 \mathrm{~h}$, rinsed with water and annealed at $450{ }^{\circ} \mathrm{C}$ for $45 \mathrm{~min}$. The electrodes were finally immersed in dye solutions that may hold chenodeoxycholic acid as co-adsorbent for $15 \mathrm{~h}$ in the dark. After rinsing the electrodes, the hole conductor layer was deposited by spin-coating from a spiro-OMeTAD (Solaronix) solution in chlorobenzene $\left(180 \mathrm{mg}^{\mathrm{mL}} \mathrm{m}^{-1}\right)$ containing tert-butylpyridine and LiTFSI as additives, following a reported recipe [45]. Gold top electrodes were finally evaporated under vacuum $\left(10^{-6}\right.$ mbar $)$ using shadow masks that define two active areas per substrate (around $0.15 \mathrm{~cm}^{2}$ each).

\subsection{Characterization of Solar Cells}

The J-V measurements, in the dark and under illumination, were performed in air using a Keithley model 2400 digital source meter by applying independent external voltage to the cell and by measuring the photogenerated current out from the cell. The spectral mismatch between the emission solar simulator (Newport 1600W) and the global AM1.5G solar spectrum was corrected using a mismatch factor and the solar simulator irradiance was adjusted accordingly using a certified silicon reference cell in order to achieve an equivalent AM1.5G irradiance of one sun $\left(100 \mathrm{~mW} \cdot \mathrm{cm}^{-2}\right)$ on the test cells. The incident photon to current efficiency (IPCE) was estimated using a monochromated $75 \mathrm{~W}$ xenon lamp (Newport). The photocurrent, measured in static regime by a calibrated picoammeter (Keithley 485), was compared to the calibration current response recorded using a certified calibrated photodiode (Newport). All data shown in this work were the average values of at least four parallel tests.

\subsection{Fabrication of Solar Cells for EPR Experiments}

FTO slides were washed and sonicated five times for 15 min each in water, ethanol, twice in isopropanol and finally, analytical grade ethanol. FTO- $\mathrm{TiO}_{2}$ (18 NRT Solaronix) films were prepared by "doctor blading" (uniformly spreading $\mathrm{TiO}_{2}$ paste on a pre-defined area of $1.25 \mathrm{~cm}^{2}$ on FTO glass with a glass bar). The FTO electrode was then left for $30 \mathrm{~min}$ on an oven at $450{ }^{\circ} \mathrm{C}$ in order to sinter the anatase crystals. The dye adsorption on $\mathrm{FTO}-\mathrm{TiO}_{2}$ film electrodes was carried out by heating the electrodes for $10 \mathrm{~min}$ at $75{ }^{\circ} \mathrm{C}$ on a hot plate, followed by immersion into a single dye solution in $50 \%$ acetonitrile $50 \% \mathrm{tBuOH}$ for a given time of $16 \mathrm{~h}$. The DSSCs were electrically characterized by the use of a solar simulator (Newport model 96,000 Oriel), equipped with a $150 \mathrm{~W}$ ozone free xenon lamp, and a digital multimeter (Keithley 2600A) connected to a computer that used dedicated software for test running.

\subsection{EPR Characterization of Solar Cells}

Before performing the EPR analysis of the complete DSSC, it was necessary to measure the solar cell electrical performance in the absence and the presence of the spin probe. Indeed, only cells showing well-measurable and reproducible electrical performances (not reported) were tested by EPR. After measuring their electrical functionality, the cells were placed on the EPR cavity where a static magnetic field is applied while a source of microwaves is also applied to the sample. This allows the resonance condition that is necessary to promote the probe (4C-T) signal. EPR spectra were recorded with an EMX-Bruker spectrometer operating at the X band $(9.5 \mathrm{GHz})$ and interfaced with a PC (software from Bruker for handling and recording the EPR spectra). The EPR spectra were simulated with the NLSL software [58].

\subsection{Transient Photovoltage Decay Mesurements}

Transient photovoltage measurements were done on the cells illuminated by a bias light provided by white LED of variable intensity [59]. An additional light pulse was superimposed using a $550 \mathrm{~nm}$ green LED, and the transient electrical response of the cell was recorded in open-circuit conditions 
using the high impedance input of a digital oscilloscope (Tektronix DPO4032, Tektronix, Bracknell, UK) Transient photovoltage curves were fitted using mono-exponential functions, ensuring a perturbing regime where the transient photogenerated charge density was kept below $1 \%$ of the stead-state photogenerated charge density.

\section{Conclusions}

A series of chlorophyll derivatives M1-M6 equipped with either a non-conjugated carboxy or a conjugated acrylic or cyanoacrylic anchoring group was prepared for their use as dye component in all-solid state DSSCs. The use of a co-adsorbent was found to be crucial to improve the device performance by avoiding the chlorin dye aggregation. The solar energy conversion efficiencies of DSSCs bearing the acrylic group (M3-M4) were larger than those bearing the cyanoacrylic group (M5-M6). The weakest performances of M5-M6 compared to M3-M4 were attributed to several factors: (i) a faster recombination kinetic at the titania/electrolyte interface, (ii) the position of the LUMO below the $\mathrm{TiO}_{2}$ conduction band is not suitable for electron injection, and (iii) a lower amount adsorbed onto the $\mathrm{TiO}_{2}$ surface. Nevertheless, although M1-M2 exhibited not suitable features in terms of recombination kinetics and dye adsorption, higher PCEs were obtained which may suggest that M1-M2 molecules have a suitable orientation on the $\mathrm{TiO}_{2}$ surface due the larger flexibility of the alkyl spacer, which may lead to improved charge transfer. This question will be addressed in future investigations as well as their long-term stability.

Author Contributions: M.C. (Michèle Chevrier) carried out the synthesis of the chlorophyll derivatives, prepared the chlorin-based DSSCs, analyzed their photovoltaic performances and wrote a part of this paper. C.K. and C.R. participated to the synthesis of MPPa precursor. M.S. participated to the study of the optical properties of the chlorin dyes. A.F. performed the EPR analysis and wrote the related part in the manuscript. M.C. (Michela Cangiotti) helped to record the EPR spectra. M.F.O. simulate the EPR spectra. L.L. and D.B. performed the DFT calculations. R.L. (PhD co-supervisor of M.C. (Michèle Chevrier) in Belgium), P.D. (PhD co-supervisor of M.C. (Michèle Chevrier) in Belgium) and A.M. (PhD supervisor of M.C. (Michèle Chevrier) in France) participated to the early research. J.B. supervised the ssDSSC fabrication and characterization, including TPV measurements. S.R. and S.C. participated to the early research, supervised the research and wrote the paper. All authors have read and agreed to the published version of the manuscript.

Funding: This research was funded by CNRS, PEPS “Caesar" from the 2017 call from l'INSIS and Région Languedoc-Roussillon (Research Grant "Chercheur(se)s d'Avenir-2015-005984) and the FEDER program (Fonds Européen de Développement Régional).

Acknowledgments: The authors thank the Université de Montpellier for financial support. S.R and S.C. also thanks Phyco-biotech for providing spirulina. Research in Mons is supported by FNRS-FRFC (through the Excellence of Science '2Dto3D' project and Consortium des Equipements de Calcul Intensif-CECI) and the European Commission and Région Wallonne (through the FEDER BIORG-EL project). M.S and D.B. are FNRS senior research associate and research director, respectively. J.B. acknowledges the PLATINOM technologic platform at XLIM (and common facility of the University of Limoges), as well as the SIGMALIM Laboratory of Excellence.

Conflicts of Interest: The authors declare no conflict of interest.

\section{References and Note}

1. Barnham, K.W.J.; Mazzer, M.; Clive, B. Resolving the energy crisis: Nuclear or photovoltaics? Nat. Mater. 2006, 5, 161-164. [CrossRef]

2. Blankenship, R.E.; Tiede, D.M.; Barber, J.; Brudvig, G.W.; Fleming, G.; Ghirardi, M.; Gunner, M.R.; Junge, W.; Kramer, D.M.; Melis, A.; et al. Comparing Photosynthetic and Photovoltaic Efficiencies and Recognizing the Potential for Improvement. Science 2011, 332, 805. [CrossRef] [PubMed]

3. Zhang, T.; Liu, C.; Dong, W.; Wang, W.; Sun, Y.; Chen, X.; Yang, C.; Dai, N. Photoelectrochemical Complexes of Fucoxanthin-Chlorophyll Protein for Bio-Photovoltaic Conversion with a High Open-Circuit Photovoltage. Chem. Asian J. 2017, 12, 2996-2999. [CrossRef] [PubMed]

4. Yu, Z.; You, S.; Wang, C.; Bu, C.; Bai, S.; Zhou, Z.; Tai, Q.; Liu, W.; Guo, S.; Zhao, X.-z. Efficient dye-sensitized solar cells employing highly environmentally-friendly ubiquinone 10 based I2-free electrolyte inspired by photosynthesis. J. Mater. Chem. A 2014, 2, 9007-9010. [CrossRef] 
5. Calogero, G.; Bartolotta, A.; Di Marco, G.; Di Carlo, A.; Bonaccorso, F. Vegetable-based dye-sensitized solar cells. Chem. Soc. Rev. 2015, 44, 3244-3294. [CrossRef] [PubMed]

6. Ammar, A.M.; Mohamed, H.S.H.; Yousef, M.M.K.; Abdel-Hafez, G.M.; Hassanien, A.S.; Khalil, A.S.G. Dye-Sensitized Solar Cells (DSSCs) Based on Extracted Natural Dyes. J. Nanomater. 2019, 2019, 10. [CrossRef]

7. Quintana, N.; Van der Kooy, F.; Van de Rhee, M.D.; Voshol, G.P.; Verpoorte, R. Renewable energy from Cyanobacteria: Energy production optimization by metabolic pathway engineering. Appl. Microbiol. Biotechnol. 2011, 91, 471-490. [CrossRef]

8. Sarma, M.K.; Kaushik, S.; Goswami, P. Cyanobacteria: A metabolic power house for harvesting solar energy to produce bio-electricity and biofuels. Biomass Bioenergy 2016, 90, 187-201. [CrossRef]

9. Wondraczek, L.; Batentschuk, M.; Schmidt, M.A.; Borchardt, R.; Scheiner, S.; Seemann, B.; Schweizer, P.; Brabec, C.J. Solar spectral conversion for improving the photosynthetic activity in algae reactors. Nat. Commun. 2013, 4, 2047. [CrossRef]

10. Calvin, M. Solar Energy by Photosynthesis. Science 1974, 184, 375. [CrossRef]

11. O'Regan, B.; Grätzel, M. A low-cost, high-efficiency solar cell based on dye-sensitized colloidal $\mathrm{TiO}_{2}$ films. Nature 1991, 353, 737-740. [CrossRef]

12. Grätzel, M. Recent Advances in Sensitized Mesoscopic Solar Cells. Acc. Chem. Res. 2009, 42, 1788-1798. [CrossRef] [PubMed]

13. Mathew, S.; Yella, A.; Gao, P.; Humphry-Baker, R.; Curchod, B.F.E.; Ashari-Astani, N.; Tavernelli, I.; Rothlisberger, U.; Nazeeruddin, M.K.; Grätzel, M. Dye-sensitized solar cells with $13 \%$ efficiency achieved through the molecular engineering of porphyrin sensitizers. Nat. Chem. 2014, 6, 242. [CrossRef]

14. Kakiage, K.; Aoyama, Y.; Yano, T.; Oya, K.; Fujisawa, J.-i.; Hanaya, M. Highly-efficient dye-sensitized solar cells with collaborative sensitization by silyl-anchor and carboxy-anchor dyes. Chem. Commun. 2015, 51, 15894-15897. [CrossRef] [PubMed]

15. Hardin, B.E.; Snaith, H.J.; McGehee, M.D. The renaissance of dye-sensitized solar cells. Nat. Photonics 2012, 6, 162-169. [CrossRef]

16. Jung, H.S.; Lee, J.-K. Dye Sensitized Solar Cells for Economically Viable Photovoltaic Systems. J. Phys. Chem. Lett. 2013, 4, 1682-1693. [CrossRef] [PubMed]

17. Chevrier, M.; Hawashin, H.; Richeter, S.; Mehdi, A.; Surin, M.; Lazzaroni, R.; Dubois, P.; Ratier, B.; Bouclé, J.; Clément, S. Well-designed poly(3-hexylthiophene) as hole transporting material: A new opportunity for solid-state dye-sensitized solar cells. Synth. Met. 2017, 226, 157-163. [CrossRef]

18. Benesperi, I.; Michaels, H.; Freitag, M. The researcher's guide to solid-state dye-sensitized solar cells. J. Mater. Chem. C 2018, 6, 11903-11942. [CrossRef]

19. Bouclé, J.; Ackermann, J. Solid-state dye-sensitized and bulk heterojunction solar cells using $\mathrm{TiO}_{2}$ and $\mathrm{ZnO}$ nanostructures: Recent progress and new concepts at the borderline. Polym. Int. 2012, 61, 355-373. [CrossRef]

20. Cao, Y.; Saygili, Y.; Ummadisingu, A.; Teuscher, J.; Luo, J.; Pellet, N.; Giordano, F.; Zakeeruddin, S.M.; Moser, J.E.; Freitag, M.; et al. 11\% efficiency solid-state dye-sensitized solar cells with copper(II/I) hole transport materials. Nat. Commun. 2017, 8, 15390. [CrossRef]

21. Zhang, W.; Wu, Y.; Bahng, H.W.; Cao, Y.; Yi, C.; Saygili, Y.; Luo, J.; Liu, Y.; Kavan, L.; Moser, J.-E.; et al. Comprehensive control of voltage loss enables $11.7 \%$ efficient solid-state dye-sensitized solar cells. Energy Environ. Sci. 2018, 11, 1779-1787. [CrossRef]

22. Best Research-Cell Efficiencies. Available online: https://www.nrel.gov/pv/assets/pdfs/best-research-cellefficiencies.20190923.pdf (accessed on 2 January 2019).

23. Adeloye, A.O.; Ajibade, P.A. Towards the Development of Functionalized PolypyridineLigands for Ru(II) Complexes as Photosensitizers inDye-Sensitized Solar Cells (DSSCs). Molecules 2014, 19, 12421-12460. [CrossRef]

24. Qin, Y.; Peng, Q. Ruthenium Sensitizers and Their Applications in Dye-Sensitized Solar Cells. Int. J. Photoenergy 2012, 2012, 21. [CrossRef]

25. Ji, J.-M.; Zhou, H.; Kim, H.K. Rational design criteria for D- $\pi-A$ structured organic and porphyrin sensitizers for highly efficient dye-sensitized solar cells. J. Mater. Chem. A 2018, 6, 14518-14545. [CrossRef]

26. The yield of $12 \mathrm{~g}$ of chlorophyll an extracted from $1 \mathrm{~kg}$ of spirulina is based on an ethanolic extraction of spirulina obtained as a dry green powder from Algosud®. 
27. Agostiano, A.; Catucci, L.; Cosma, P.; Fini, P. Aggregation processes and photophysical properties of chlorophyll a in aqueous solutions modulated by the presence of cyclodextrins. Phys. Chem. Chem. Phys. 2003, 5, 2122-2128. [CrossRef]

28. Wang, X.-F.; Tamiaki, H.; Wang, L.; Tamai, N.; Kitao, O.; Zhou, H.; Sasaki, S.-I. Chlorophyll-a Derivatives with Various Hydrocarbon Ester Groups for Efficient Dye-Sensitized Solar Cells: Static and Ultrafast Evaluations on Electron Injection and Charge Collection Processes. Langmuir 2010, 26, 6320-6327. [CrossRef]

29. Sasaki, S.-i.; Wang, X.-F.; Ikeuchi, T.; Tamiaki, H. Synthesis of carboxylated chlorophylls and their application as functional materials. J. Porphyr. Phthalocyanines 2015, 19, 517-526. [CrossRef]

30. Tamiaki, H.; Hagio, N.; Tsuzuki, S.; Cui, Y.; Zouta, T.; Wang, X.-F.; Kinoshita, Y. Synthesis of carboxylated chlorophyll derivatives and their activities in dye-sensitized solar cells. Tetrahedron 2018, 74, 4078-4085. [CrossRef]

31. Li, Y.; Zhao, W.; Li, M.; Chen, G.; Wang, X.-F.; Fu, X.; Kitao, O.; Tamiaki, H.; Sakai, K.; Ikeuchi, T.; et al. Chlorophyll-Based Organic-Inorganic Heterojunction Solar Cells. Chem. Eur. J. 2017, 23, 10886-10892. [CrossRef]

32. Zhao, W.; Sasaki, S.-I.; Tamiaki, H.; Sanehira, Y.; Wei, Y.; Chen, G.; Wang, X.-F. Enhancement of performance in chlorophyll-based bulk-heterojunction organic-inorganic solar cells upon aggregate management via solvent engineering. Org. Electron. 2018, 59, 419-426. [CrossRef]

33. Cui, Y.; Zhao, W.; Ogasawara, S.; Wang, X.-F.; Tamiaki, H. Fabrication and performance of all-solid-state dye-sensitized solar cells using synthetic carboxylated and pyridylated chlorophyll derivatives. J. Photochem. Photobiol. A 2018, 353, 625-630. [CrossRef]

34. Smith, K.M.; Goff, D.A.; Simpson, D.J. The meso substitution of chlorophyll derivatives: Direct route for transformation of bacteriopheophorbides d into bacteriopheophorbides c. J. Am. Chem. Soc. 1985, 107, 4946-4954. [CrossRef]

35. Tamiaki, H.; Amakawa, M.; Shimono, Y.; Tanikaga, R.; Holzwarth, A.R.; Schaffner, K. Synthetic Zinc and Magnesium Chlorin Aggregates as Models for Supramolecular Antenna Complexes in Chlorosomes of Green Photosynthetic Bacteria. Photochem. Photobiol. 1996, 63, 92-99. [CrossRef]

36. Sun, L.; Wang, S. Spectral and nonlinear optical properties of chlorophyll b depends on distortion of two-dimensional electron configuration along one axis. Dyes Pigm. 2004, 61, 273-278. [CrossRef]

37. Li, Y.; Sasaki, S.-i.; Tamiaki, H.; Liu, C.-L.; Song, J.; Tian, W.; Zheng, E.; Wei, Y.; Chen, G.; Fu, X.; et al. Zinc chlorophyll aggregates as hole transporters for biocompatible, natural-photosynthesis-inspired solar cells. J. Power Sources 2015, 297, 519-524. [CrossRef]

38. Jungsuttiwong, S.; Sirithip, K.; Prachumrak, N.; Tarsang, R.; Sudyoadsuk, T.; Namuangruk, S.; Kungwan, N.; Promarak, V.; Keawin, T. Significant enhancement in the performance of porphyrin for dye-sensitized solar cells: Aggregation control using chenodeoxycholic acid. New J. Chem. 2017, 41, 7081-7091. [CrossRef]

39. Kay, A.; Graetzel, M. Artificial photosynthesis. 1. Photosensitization of titania solar cells with chlorophyll derivatives and related natural porphyrins. J. Phys. Chem. 1993, 97, 6272-6277. [CrossRef]

40. Lee, K.-M.; Suryanarayanan, V.; Ho, K.-C.; Justin Thomas, K.R.; Lin, J.T. Effects of co-adsorbate and additive on the performance of dye-sensitized solar cells: A photophysical study. Sol. Energy Mat. Sol. Cells 2007, 91, 1426-1431. [CrossRef]

41. Yum, J.-H.; Jang, S.-r.; Humphry-Baker, R.; Grätzel, M.; Cid, J.-J.; Torres, T.; Nazeeruddin, M.K. Effect of Coadsorbent on the Photovoltaic Performance of Zinc Pthalocyanine-Sensitized Solar Cells. Langmuir 2008, 24, 5636-5640. [CrossRef]

42. Lu, H.-P.; Tsai, C.-Y.; Yen, W.-N.; Hsieh, C.-P.; Lee, C.-W.; Yeh, C.-Y.; Diau, E.W.-G. Control of Dye Aggregation and Electron Injection for Highly Efficient Porphyrin Sensitizers Adsorbed on Semiconductor Films with Varying Ratios of Coadsorbate. J. Phys. Chem. C 2009, 113, 20990-20997. [CrossRef]

43. Qu, S.; Wu, W.; Hua, J.; Kong, C.; Long, Y.; Tian, H. New Diketopyrrolopyrrole (DPP) Dyes for Efficient Dye-Sensitized Solar Cells. J. Phys. Chem. C 2010, 114, 1343-1349. [CrossRef]

44. Nazeeruddin, M.K.; Humphry-Baker, R.; GrÄTzel, M.; WÖHrle, D.; Schnurpfeil, G.; Schneider, G.; Hirth, A.; Trombach, N. Efficient Near-IR Sensitization of Nanocrystalline $\mathrm{TiO}_{2}$ Films by Zinc and Aluminum Phthalocyanines. J. Porphyr. Phthalocyanines 1999, 3, 230-237. [CrossRef]

45. Melhem, H.; Simon, P.; Beouch, L.; Goubard, F.; Boucharef, M.; Di Bin, C.; Leconte, Y.; Ratier, B.; Herlin-Boime, N.; Bouclé, J. $\mathrm{TiO}_{2}$ Nanocrystals Synthesized by Laser Pyrolysis for the Up-Scaling of Efficient Solid-State Dye-Sensitized Solar Cells. Adv. Energy Mater. 2011, 1, 908-916. [CrossRef] 
46. Schmidt-Mende, L.; Bach, U.; Humphry-Baker, R.; Horiuchi, T.; Miura, H.; Ito, S.; Uchida, S.; Grätzel, M. Organic Dye for Highly Efficient Solid-State Dye-Sensitized Solar Cells. Adv. Mater. 2005, 17, 813-815. [CrossRef]

47. Erten-Ela, S.; Ocakoglu, K.; Tarnowska, A.; Vakuliuk, O.; Gryko, D.T. Performance of zinc chlorophyll based molecules for dye sensitized solar cell. Dyes Pigm. 2015, 114, 129-137. [CrossRef]

48. Ocakoglu, K.; Erten-Ela, S.; Saleem Joya, K.; Harputlu, E. Artificial zinc chlorin dyes for dye sensitized solar cell. Inorg. Chim. Acta 2016, 439, 30-34. [CrossRef]

49. Dhafina, W.A.; Daud, M.Z.; Salleh, H. The sensitization effect of anthocyanin and chlorophyll dyes on optical and photovoltaic properties of zinc oxide based dye-sensitized solar cells. Optik 2019, 163808. [CrossRef]

50. Panda, B.B.; Mahapatra, P.K.; Ghosh, M.K. Application of Chlorophyll as Sensitizer for ZnS Photoanode in a Dye-Sensitized Solar Cell (DSSC). J. Electron. Mater. 2018, 47, 3657-3665. [CrossRef]

51. Wang, X.-F.; Kitao, O.; Zhou, H.; Tamiaki, H.; Sasaki, S.-i. Extension of $\pi$-conjugation length along the Qy axis of a chlorophylla derivative for efficient dye-sensitized solar cells. Chem. Commun. 2009, 1523-1525. [CrossRef]

52. Sun, Y.; Wang, X.-F.; Chen, G.; Zhan, C.-H.; Kitao, O.; Tamiaki, H.; Sasaki, S.-i. Near-infrared absorption carboxylated chlorophyll-a derivatives for biocompatible dye-sensitized hydrogen evolution. Int. J. Hydrog. Energy 2017, 42, 15731-15738. [CrossRef]

53. Fattori, A.; Cangiotti, M.; Fiorani, L.; Lucchi, S.; Ottaviani, M.F. Characterization of the $\mathrm{TiO}_{2} / \mathrm{Dye}_{\text {Electrolyte }}$ Interfaces in Dye-Sensitized Solar Cells by Means of a Titania-Binding Nitroxide. Langmuir 2014, 30, 13570-13580. [CrossRef] [PubMed]

54. Boucher, L.J.; Katz, J.J. Aggregation of metallochlorophylls. J. Am. Chem. Soc. 1967, 89, 4703-4708. [CrossRef]

55. Tamiaki, H.; Yagai, S.; Miyatake, T. Synthetic zinc tetrapyrroles complexing with pyridine as a single axial ligand. Bioorg. Med. Chem. 1998, 6, 2171-2178. [CrossRef]

56. Wang, X.-F.; Koyama, Y.; Wada, Y.; Sasaki, S.-i.; Tamiaki, H. A dye-sensitized solar cell using pheophytin-carotenoid adduct: Enhancement of photocurrent by electron and singlet-energy transfer and by suppression of singlet-triplet annihilation due to the presence of the carotenoid moiety. Chem. Phys. Lett. 2007, 439, 115-120. [CrossRef]

57. Frisch, M.J.; Trucks, G.W.; Schlegel, H.B.; Scuseria, G.E.; Robb, M.A.; Cheeseman, J.R.; Scalmani, G.; Barone, V.; Mennucci, B.; Petersson, G.A.; et al. Electronic Supplementary Material(ESI) for Chemical Science. Available online: http://www.rsc.org/suppdata/c5/sc/c5sc02423d/c5sc02423d1.pdf (accessed on 2 January 2019).

58. Khairy, K.; Budil, D.; Fajer, P. Nonlinear-least-squares analysis of slow motional regime EPR spectra. J. Magn. Reson. 2006, 183, 152-159. [CrossRef]

59. O'Regan, B.C.; Lenzmann, F. Charge Transport and Recombination in a Nanoscale Interpenetrating Network of n-Type and p-Type Semiconductors: Transient Photocurrent and Photovoltage Studies of $\mathrm{TiO}_{2} / \mathrm{Dye}_{\mathrm{CuSCN}}$ Photovoltaic Cells. J. Phys. Chem. B 2004, 108, 4342-4350. [CrossRef]

Sample Availability: Samples of the compounds M1-M6 are available from the authors.

(C) 2020 by the authors. Licensee MDPI, Basel, Switzerland. This article is an open access article distributed under the terms and conditions of the Creative Commons Attribution (CC BY) license (http://creativecommons.org/licenses/by/4.0/). 